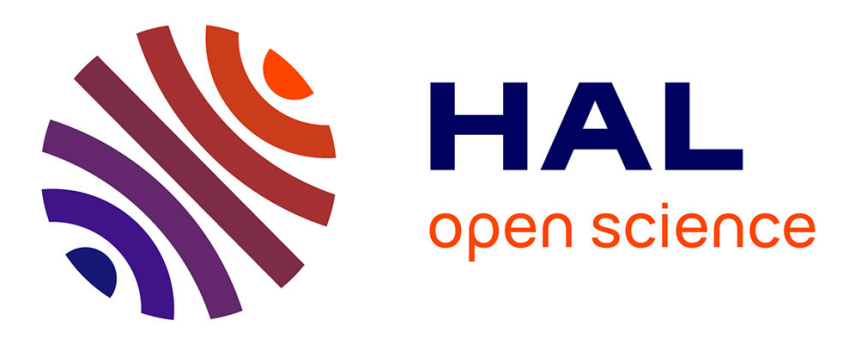

\title{
Giving Sense to and Making Sense of Justice in Postmerger Integration
}

\author{
Philippe Monin, Niels Noorderhaven, Eero Vaara, David Kroon
}

\section{To cite this version:}

Philippe Monin, Niels Noorderhaven, Eero Vaara, David Kroon. Giving Sense to and Making Sense of Justice in Postmerger Integration. Academy of Management Journal, 2013, 56 (1), pp.256-284 P. hal-02276708

\section{HAL Id: hal-02276708 \\ https://hal.science/hal-02276708}

Submitted on 3 Sep 2019

HAL is a multi-disciplinary open access archive for the deposit and dissemination of scientific research documents, whether they are published or not. The documents may come from teaching and research institutions in France or abroad, or from public or private research centers.
L'archive ouverte pluridisciplinaire HAL, est destinée au dépôt et à la diffusion de documents scientifiques de niveau recherche, publiés ou non, émanant des établissements d'enseignement et de recherche français ou étrangers, des laboratoires publics ou privés. 


\title{
GIVING SENSE TO AND MAKING SENSE OF JUSTICE IN POSTMERGER INTEGRATION
}

\author{
PHILIPPE MONIN \\ EMLYON Business School
}

NIELS NOORDERHAVEN

Tilburg University

\author{
EERO VAARA \\ DAVID KROON \\ VU University Amsterdam
}

Hanken School of Economics and EMLYON Business School

\begin{abstract}
The objective of this article is to elucidate how justice in general and distributive justice in particular are given sense to and made sense of in postmerger integration. Drawing on a longitudinal real-time analysis of a recent merger, we identify a pattern in which focus moved from equality to equity to less emphasis on distributive justice. To understand the dynamics involved, we develop a process model that explains how actors reconcile pressures of value creation and sociopolitical concerns in dialogical "sensegiving" and "sensemaking" processes that lead to the enactment of specific norms of justice. This analysis adds to research on mergers and acquisitions by facilitating understanding of the crucial role that norms of justice play in postmerger integration, of the way in which they change over time as integration processes unfold, and of the intergroup dynamics through which these norms of justice are enacted. By uncovering the microdynamics of dialogical sensegiving and sensemaking processes, we also contribute to research on organizational justice, sensemaking, and process studies.
\end{abstract}

Organizational justice plays a central role in mergers and acquisitions (M\&As). This is especially the case with postmerger integration, which involves changes that are often difficult to understand or accept in their own right (Clark, Gioia, Ketchen, \& Thomas, 2010; Graebner, 2004; Maguire \& Phillips, 2008). Legitimating organizational changes requires a sense of justice (Ellis, Reus, \& Lamont, 2009; Meyer, 2001). Perceptions of organizational justice help people to accept the planned changes and their implications, whereas perceptions of injustice exacerbate organizational problems (Meyer \& Altenborg, 2007; Zaheer, Schomaker, \& Genc, 2003). Although justice is a central tenet in all kinds of postmerger integration pro-

We are greatly indebted to special issue guest editor Ann Langley for her extraordinarily constructive guidance in our paper's revision process. We also thank Tessa Melkonian, Audrey Rouzies, Guillaume Soenen, and Alma Timmers for their role in the data collection process; PikkaMaaria Laine, Saku Mantere, and Henri Schildt for giving critical comments on various earlier versions of the article; and David Miller for language editing. cesses, it is especially so in "symbiotic" mergers involving expectations of reciprocity and equal treatment rather than dominance by either party (Haspeslagh \& Jemison, 1991; Zaheer et al., 2003).

In this article, we argue that, in addition to understanding perceptions of justice per se, understanding of their temporal dynamics is needed. In particular, clarity is needed about how "sensemaking" about justice affects the course of postmerger integration. For instance, in a move that was announced as a merger of equals, Daimler-Benz acquired Chrysler Corporation in 1998. However, almost immediately after the acquisition, Chrysler directors were sidelined or replaced until the board was practically all-German. In a later interview, CEO Jürgen Schrempp claimed that this had been his intention from the outset, but, like a chess player, he did not always reveal his next moves (Vlasic \& Stertz, 2000: 371). The result of this duplicity was disastrous: "Careers were derailed, promotions were denied, reputations sullied, and there was hometown humiliation and public derision" (Badrtalei \& Bates, 2007: 311, quoting from Automotive News). 
To better understand these organizational dynamics, we aim to elucidate how justice is given sense to and made sense of in unfolding postmerger integration processes. Our intention is not merely to examine the antecedents or consequences of individuals' perceptions of (in)justice, but also to explain how the very norms of justice that define what is fair and appropriate are socially constructed and managed. These norms can be seen as fundamental "rules of the game" that impact the course of postmerger integration processes.

Norms of justice include several aspects: a distributive aspect (relating to fair distribution of resources, roles, and responsibilities), a procedural aspect (fairness in decision making), an informational aspect (justification of decisions), and an interpersonal aspect (fairness in interpersonal relationships) (Colquitt, Conlon, Wesson, Porter, \& Ng, 2001; Luo, 2007). All of these aspects are relevant in M\&As, and they are usually closely related (Citera \& Rentsch, 1993; Ellis et al., 2009). However, in symbiotic mergers, issues related to the distribution of resources, roles, and responsibilities as well as rationalizations and cutbacks are at the forefront, and there are expectations of concrete and symbolic fairness as to how the merger parties are treated in the context of such issues (Meyer, 2001; Zaheer et al., 2003). This involves distributive norms-or allocation rules (Deutsch, 1985; Kabanoff, 1991) — such as equality (equal treatment of the merger parties in integration decisions) and equity (focus on what is fair in view of the parties' contributions), which may be interpreted in different ways in the course of postmerger integration. Thus, distributive justice has an accentuated role in symbiotic M\&As, and hence we focus on this aspect of justice in our processual analysis.

Our study builds on social construction and on becoming rather than on an essentialist or static understanding of organizational phenomena (Hernes \& Maitlis, 2010). Previous studies adopting a process perspective on M\&As (Clark et al., 2010; Jemison \& Sitkin, 1986) have shown that postmerger processes tend to generate unintended consequences-both problems (Vaara \& Monin, 2010) and opportunities for value creation (Graebner, 2004). We want to extend this process view by conceptualizing postmerger integration as a sensemaking process in which norms of justice play a central role in steering the course of integration. These sensemaking activities are complex; they involve actors in a variety of positions whose interactions determine whether specific norms are enacted (Maitlis, 2005). In particular, these activities comprise both purposeful sensegiving and reac- tions to sensegiving in the form of member sensemaking (Maitlis \& Lawrence, 2007).

We draw from a real-time, longitudinal, exploratory study of postmerger integration in the recent merger between two European logistics companies, Southco and Northco (pseudonyms). This extensive research project was carried out by a transnational research team that gathered data including interviews, documents, and other information about postmerger integration in general and justice in particular. Through our process analysis, we identified a clear pattern in which the focus of sensegiving and sensemaking moved from equality to equity to less attention on distributive justice per se. We then proceeded to explain this pattern by developing a process model of the role of justice in postmerger integration. In this model, dialectical pressures for value creation (changes needed to increase efficiency and effectiveness) and sociopolitical concerns (problems related to uncertainty, resistance, cultural clashes, and identification) trigger a need for sensegiving and sensemaking about justice. In the core of this model are sensegiving acts that comprise "sensebreaking" (breaking previously established senses of justice), sense specification (providing specific meanings to justice), and "sensehiding" (deliberately avoiding particular senses of justice). Sensemaking in the form of members' reactions consists of acceptance (acceptance of specific senses of justice), resistance (resistance to senses of justice), and distancing (taking distance from senses of justice). The dialogical dynamics of sensegiving and sensemaking then determine how specific norms of justice are enacted, the degree of ambiguity around the norms of justice, and the extent to which managers' and other members' views on justice align in a postmerger organization at a given point of time.

This analysis adds to research on M\&As by furthering understanding of the crucial role that norms of justice in general and distributive justice in particular play in postmerger integration, the way in which they change over time as integration processes unfold, and the intergroup dynamics through which these norms of justice are created and enacted. By highlighting the social construction of norms of justice, we also open up new avenues in research on organizational justice. By distinguishing how sensebreaking, sense specification, and sensehiding affect the dynamics of organizational sensemaking, our analysis adds to research on the dynamics of sensegiving and sensemaking. Finally, by explaining how the underlying dialectics of value creation and sociopolitical concerns are given sense to and made sense of in dialogical processes, our model may be more 
generally useful for process studies of organizational change.

\section{A SENSEMAKING APPROACH TO JUSTICE IN POSTMERGER INTEGRATION}

\section{Postmerger Integration}

Postmerger integration is a complex organizational process that involves difficult managerial challenges. On the one hand, there is a need to create synergy (Larsson \& Finkelstein, 1999) or value (Haspeslagh \& Jemison, 1991) through organizational changes. On the other hand, these very changes tend to generate uncertainty (Cording, Christmann, \& King, 2008), resistance (Buono \& Bowditch, 1989), culture clashes (Stahl \& Voigt, 2008), identity problems (Maguire \& Phillips, 2008), and organizational politics (Graebner, 2004). Dealing with the tensions between value creation and sociopolitical concerns appears to be the crux of postmerger integration management (Haspeslagh \& Jemison, 1991; Larsson, 1990; Walter, 1985). Scholars have explored various aspects of this daunting task, such as the importance of combining coordinative efforts with measures to avoid employee resistance (Larsson, 1990), the necessity of synchronizing task integration and human integration (Birkinshaw, Bresman, \& Håkanson, 2000), and the need to balance interdependence with autonomy (Graebner, 2004; Haspeslagh \& Jemison, 1991). Importantly for our purposes, the potential tensions between value creation and sociopolitical concerns are particularly strong when close cooperation is needed without one firm dominating the other-that is, in mergers of the "symbiotic" (Haspeslagh \& Jemison, 1991), "equality/conflict" (Larsson, 1990), or "collaboration/synergy" types (Napier, 1989). These types of mergers (which we will refer to as symbiotic) are characterized by a heightened sensitivity to justice among people affected by them (Zaheer et al., 2003). Thus, there is a special need for rules of the game that define what is fair in dealing with postmerger integration challenges.

We argue that it is important to examine these rules of the game from a processual perspective. Landmark studies have emphasized the dynamic nature of M\&As (Jemison \& Sitkin, 1986; Larsson, 1990). More recent analyses have in turn demonstrated how unfolding organizational changes create new problems and challenges (Clark et al., 2010; Schweizer, 2005; Vaara \& Monin, 2010). Although these studies have not focused on justice, they all suggest that the way in which managers are able to deal with shifts in the rules of the game has a fundamental impact on the course of integration. Thus, there is a need to examine in more depth how norms of justice as rules of the game are made sense of in unfolding integration processes and how they may be managed.

\section{Norms of Justice as Social Constructions}

Philosophers (e.g., Rawls, 1971), political scientists (e.g., Walton \& McKersie, 1965), social psychologists (e.g., Adams, 1965), and sociologists (e.g., Rubinstein, 1988) have examined justice as an inherent part of social life. Management scholars have studied justice at the individual, group, and organizational levels (Ambrose \& Cropanzano, 2003; Colquitt et al., 2001; Colquitt \& Rodell, 2011). This research has covered different dimensions of organizational justice, including distributive, procedural, informational, and interpersonal justice (Colquitt et al., 2001; McFarlin \& Sweeney, 1992). These various dimensions of justice are interlinked (Luo, 2007). For example, a decision concerning a fair allocation of resources (distributive justice) should be accomplished in a just process (procedural justice), involve proper justifications (informational justice), and involve nurturing of relationships (interpersonal justice). Consequently, although we primarily focus on distributive justice here, the actual issues are also closely connected to other aspects of justice.

Distributive justice deals with issues of bargaining, resource allocation, and allotment of outcomes, as well as the norms of justice associated with these activities (Adams, 1965; Leventhal, 1976). The classical norms are equity, equality, and need. As need is a more general concern that often connects with the personal rather than the collective level, we focus on equity and equality as the norms that play a key role in organizational change (for similar reasoning, see Kabanoff [1991]). Although organizational research has mostly focused on equity, it has also been demonstrated that equality is the central norm when social relationships are in the fore. In this view, equity is the normal rule of distributive justice; it means that outcomes are distributed according to input or contribution (i.e., equitably). Equality in turn is a norm signifying the equal value of the members in a relationship; it facilitates maintenance of mutual self-esteem and positive relationships (Deutsch, 1985; Kabanoff, 1991).

Ring and Van de Ven (1994) paved the way for studies of justice in interorganizational settings by arguing that perceived justice determines the fate of organizational relationships. Since then scholars have examined various aspects of justice in alli- 
ances (Ariño \& Smith Ring, 2010; Luo, 2007) and in M\&As (Citera \& Rentsch, 1993; Meyer, 2001). Although most studies in the M\&A context have focused on distributive or procedural justice (Lipponen, Olkkonen, \& Moilanen, 2004; Meyer \& Altenborg, 2007), informational and interpersonal fairness have also been linked with value creation (Ellis et al., 2009; Klendauer \& Deller, 2009). Furthermore, studies have shown that different dimensions of justice may reinforce or weaken each other (Ellis et al., 2009). In all, this research has demonstrated that perceptions of justice have a fundamental impact on people's attitudes and behaviors (Klendauer \& Deller, 2009; Meyer \& Altenborg, 2007).

Symbiotic mergers often bring with them accentuated expectations of equality and attention to distributive justice, especially in the case of mergers of equals (Hambrick \& Cannella, 1993; Meyer, 2001). As Zaheer et al. put it: "By defining a merger as one of 'equals,' an expectation of distributive equality may be created (i.e., that every aspect of the merger will be equal), rather than one of integrative equality, where on balance, each side will gain in some areas and lose in others" (2003: 186). However, this focus on distributive rather than integrative bargaining may be at the expense of realizing synergies $^{1}$ (Walton \& McKersie, 1965). This may be a reason why other studies indicate that it is difficult to maintain consistent images of "equality" or to hold on to a "balance of power" in the long run (Hambrick \& Cannella, 1993; Very, Lubatkin, Calori, \& Veiga, 1997).

These contributions notwithstanding, little is known about how norms of justice in general and distributive justice in particular are socially constructed in the course of postmerger integrationthat is, how on the one hand management justifies integration measures by explicitly or implicitly evoking norms of justice and how on the other hand members make sense of these norms. This has unfortunately prevented researchers from fully comprehending the central role that norms of justice play as rules of the game in postmerger integration.

\section{Giving Sense to and Making Sense of Justice}

A sensemaking perspective allows one to examine the complex processes through which organi-

\footnotetext{
${ }^{1}$ In integrative bargaining, the parties search for solutions that maximize overall value. We are indebted to one of the reviewers for pointing our attention to the link with the bargaining literature.
}

zational actors socially construct their realities (Weick, 1995), hence providing a useful theoretical approach to examining the social construction of norms of justice in postmerger integration. A key idea in sensemaking is that it is triggered by issues, "events, developments, and trends that an organization's members collectively recognize as having some consequence to the organization" (Dutton \& Dukerich, 1991: 518). Accordingly, one can conceptualize postmerger integration as a process wherein anticipated and unanticipated issues trigger sensemaking. These issues often deal with fundamental questions concerning justice between and among organizations, groups, and individuals.

Sensemaking is related to sensegiving, which is the attempt to influence the sensemaking of others in a particular direction (Bartunek, Rousseau, Rudolph, \& DePalma, 2006; Maitlis, 2005). Although this sensegiving is usually seen as the work of top management, middle managers also engage in behaviors such as "selling" (Dutton \& Ashford, 1993; Rouleau, 2005). Such sensegiving is likely to play a crucial role in the social construction of norms of justice. Sensegiving in the context of postmerger integration could for instance pertain to the promulgation of an appropriate principle for allocating managerial positions (e.g., equal representation or selection on the basis of competence). Fortin and Fellenz (2008: 428) underscored the importance of this "norm shaping." Through shaping, managers can influence the justice perceptions and resulting reactions of employees. Thus, managers and other organizational actors use various means, such as discourse, rhetoric, narrative, and metaphor, to create specific meanings (Watson, 2003). At times actors also engage in sensebreaking: the intentional destruction of existing meaning in an effort to facilitate change (Maitlis \& Lawrence, 2007; Mantere, Schildt, \& Sillince, 2012; Pratt, 2000). Managers may also actively avoid using particular discourses-a phenomenon that has been called "sensehiding" (Vaara \& Monin, 2010).

Sensemaking may take different forms depending on the interactions between the actors involved (Maitlis, 2005). This is also the case with norms of justice; they may be accepted, resisted, or purposefully ignored (Sonenshein, 2010; Stensaker \& Falkenberg, 2007). These reactions are crucial in determining whether the norms promoted will be followed and whether related organizational changes will be resisted. Thus, it is important to examine the dynamics of these processes in postmerger integration. This leads us to formulate our research questions as follows: How is distributive justice given sense to and made sense of in postmerger organizations? What are the dynamics that 
characterize these sensegiving and sensemaking efforts in unfolding postmerger integration processes?

\section{METHODS}

\section{Research Context}

We conducted a longitudinal real-time analysis of the merger between Southco and Northco. Both companies operated in the same service sector, but Southco was approximately twice the size of Northco in terms of turnover and number of employees. The combination took place in a booming economy, and the finances of both organizations were sound. For our purposes, this merger-formally, a friendly acquisition-served as revelatory case as it involved complex cultural and political dynamics and a special need to make sure that the merger and the subsequent postmerger integration decisions were fair. As we were able to follow the unfolding integration efforts in real time, this case can be seen as an ideal setting for analyzing organizational process dynamics.

We gained access to the case immediately after the merger plans were announced through direct contact with top management. This led to a longitudinal research project in which we researchers followed the unfolding postmerger integration processes from the beginning, for five years altogether. Although the project was designed to serve our academic research interests, it also served to provide continuous feedback to top management. We were given open access and an opportunity to gather unusually extensive and comprehensive data. The project was designed so that we could examine several research questions related to organizational change. From the start, our intention was to focus on justice; in the course of the research project, we realized that sensemaking about justice formed a fundamental part of the integration process and its management.

\section{Empirical Data}

Our empirical data comprise interviews, internal documents and communications materials, media coverage, and meetings with top and middle managers.

Interviews. Semistructured interviews served as the primary source of data. Three of the authors together with four other researchers held a series of interviews every six months for almost four years. Altogether, we conducted 682 interviews with Southco and Northco managers and employees in the most important business areas and functions in ten countries. We distinguish among top management ${ }^{2}$ (the CEOs of both companies, executive vice presidents, division heads, and country managers), middle management (heads of units and functional departments), and lower management and employees. Table 1 summarizes the distribution of interviews.

The interviews lasted from 45 to 90 minutes and were (with a few exceptions) recorded and transcribed verbatim. We conducted the interviews in three different languages, depending on the mother tongue and language skills of the interviewer and interviewee. In these semistructured one-to-one interviews, we followed a story-telling approach (Czarniawska, 2004): interviewees were able to express their experiences, without too much guidance on the part of their interviewer, by responding to broad questions such as "What do you think of the merger?" This very frequently prompted interviewees to talk about justice. Moreover, our interview protocol also comprised a range of questions dealing with postmerger integration. Specific questions about justice included the following: "Do you think the decisions taken so far are advantageous or disadvantageous to the company in general?" "What about your own function or department?"

\footnotetext{
${ }^{2}$ It should be noted that our definition of top management is broad. However, in this merger involving tens of thousands of people, the group of top decision makers was exceptionally large.
}

TABLE 1

Breakdown of Interviews $(n=682)$ by Company, Hierarchical Level, and Period ${ }^{\mathrm{a}}$

\begin{tabular}{|c|c|c|c|c|c|c|}
\hline \multirow[b]{2}{*}{ Hierarchical Level } & \multicolumn{3}{|c|}{ Southco $(n=380)$} & \multicolumn{3}{|c|}{ Northco $(n=302)$} \\
\hline & Period 1 & Period 2 & Period 3 & Period 1 & Period 2 & Period 3 \\
\hline Top management & 21 & 19 & 12 & 38 & 15 & 5 \\
\hline Middle management & 55 & 41 & 11 & 51 & 50 & 21 \\
\hline Lower management and employees & 117 & 96 & 8 & 57 & 34 & 31 \\
\hline Total & 193 & 156 & 31 & 146 & 99 & 57 \\
\hline
\end{tabular}

\footnotetext{
${ }^{a}$ Data were collected every six months. Additional details are available on request.
} 
and "The 'combination' [merger] has been said to be guided by a fairness principle. From what you observe, is that true? Why (not)?" All this allowed us to zoom in on the organizational sensegiving and sensemaking processes of people representing different parts of the organizations.

Internal documents, communications materials, and media coverage. We gathered relevant internal documentary material amounting to over 200 documents. Among 36 internal merger-related documents and presentations (e.g., reports by consulting companies such as Boston Consulting Group and extensive verbatim records of management conventions on both sides), ${ }^{3}$ we focused special attention on the most influential ones. In particular, a document labeled "agreement on integration rules between Southco and Northco" provided the basis for the governance of the merged company, and the internal document "SouthcoNorthco principles of organization and management" described the Southco-Northco modus operandi three years after its beginning. We attentively read extant monographs and books (eight altogether) on the century-long history of the partners. Furthermore, we collected a large amount of communication material. In particular, the company newsletters at both Southco and Northco (published every two weeks) provided interesting information on the framings of specific issues of debate. We also utilized selected publications by the companies' works councils. Top managers of both companies gave several public speeches and interviews that were diffused through the media, and we sampled 15 of them for "triangulation" purposes. Finally, to understand the wider discussion around the merger, we also gathered extensive media coverage (more than 100 documents), focusing on the explicit or implicit norms of justice.

Meetings with top management. Throughout the research project, we remained in contact with Southco-Northco corporate management, and this proximity provided numerous opportunities for formal and informal discussions. Notably, we reported our findings every six months to a SouthcoNorthco steering committee for our research and, upon request, to HR managers in several business areas. Key findings were presented once a year to the Southco-Northco Top Management Committee. These meetings were important opportunities to discuss our findings and validate our results (see below). Although top management learned from

\footnotetext{
${ }^{3}$ Management conventions are large meetings of top and middle managers that were held once or twice a year during the integration.
}

this feedback, we do not think that it had a decisive impact on their views regarding postmerger integration in general and justice in particular.

\section{Data Analysis}

Our analytic approach was abductive. Accordingly, we developed our theoretical ideas alongside increasingly accurate mapping of the case. After preliminary analyses, we proceeded in three stages: We carried out a detailed analysis of sensegiving and sensemaking about justice over time and across business areas and locations. We then focused on an in-depth analysis of different modes of sensegiving and sensemaking. We finally analyzed the dynamics of sensegiving, sensemaking, and enactment to develop a more general model of the role of justice in general and distributive justice in particular in postmerger integration.

Analysis of sensegiving and sensemaking over time and across business areas and locations. Drawing on all available documentary and interview material, we mapped out events and decisions in detail. We identified key issues, delineated characteristic patterns of sensegiving and sensemaking about justice across groups of people over time, and finally constructed our researchers' narrative (Langley, 1999) of this sensegiving and sensemaking. We focused on distributive justice - that is, on examples of issues related to the distribution of resources, roles, and responsibilities as well as rationalizations and cutbacks. ${ }^{4}$

In this analysis, we first focused on explicit references to justice, which provided rich material about the central role of justice in postmerger integration. However, we then realized that references to norms of justice were even more often implicit, requiring contextual interpretation and sometimes reading between the lines. For example, a country manager told us how Southco and Northco departments were merged in his organization: "Department by department we look how Southco and Northco can be linked together. People can indicate which job they would like to have most here in Sales, and which are their second and third preferences. And then we have a consultation, say an interview, with the candidates. A team of Northco and Southco people talks with them, as neutral as possible. And that ultimately should lead to appointments of the right people to the right positions." Although the interviewee did not explicitly mention justice, the focus on equity in the quote is

\footnotetext{
${ }^{4}$ However, other aspects of justice were often closely linked with issues of distributive justice.
} 
revealing, especially in contrast to the emphasis on equality in earlier interviews in the same country organization.

In this process, we identified about 40 potentially relevant issues that we explored in some depth. From these we selected eight "tracer" issues that (a) were particularly salient in terms of illustrating sensegiving and sensemaking about distributive justice, (b) were seen as important by most groups of people, (c) were representative of what happened in the merger at large or within a particular department or function, and (d) helped us to illustrate a variety of patterns of sensegiving and sensemaking about justice over time (for analogous criteria, see Maitlis and Lawrence [2007]). This also led us to distinguish three time periods. Figure 1 is a time line tracking key issues in the merger.

Analysis of modes of sensegiving and sensemaking. We then zoomed in on the various modes of sensegiving and sensemaking concerning justice and coded our interviews and relevant parts of documentary material on this basis. Figure 2 describes the coding structure of our data.

Coding led us to identify and elaborate on three main types of sensegiving: sensebreaking, sense specification, and sensehiding. Following the examples of other researchers (Mantere et al., 2012; Pratt, 2000), we defined sensebreaking as breaking down previously established senses about justice. This sensebreaking included both "problematization" of previous ways of thinking or acting (e.g., problematization of equality as the central norm of justice) and concrete rule-breaking decisions and actions. We realized that another important part of sensegiving was specification of explicit or implicit norms of justice, which we call sense specification. This sense specification could take different forms: coining of principles, exemplary decisions and actions, symbolization, and quantification. Sensehiding (Vaara \& Monin, 2010) also played a crucial role in the case, and we defined it as silencing alternative senses of integration or marginalization of particular voices.

Furthermore, we distinguished between types of member reactions as key forms of sensemaking. This led us to focus on three types of sensemaking: acceptance, resistance, and distancing. We defined acceptance as active or passive acceptance of the established or offered senses about integration (Giessner, Viki, Otten, Terry, \& Täuber, 2006). This acceptance could take the form of active support, buy-in, or reasoned agreement. We distinguished between disagreement and opposition as forms of passive and active resistance. We also realized that many people did not seem to directly accept or resist the meanings offered, but "took distance" from them instead (Piderit, 2000). Hence, we defined distancing as putting distance between oneself and the established or offered senses of integration. This distancing consisted of questioning, irony, and cynicism.

Analysis of dynamics of sensegiving, sensemaking, and enactment. Finally, we proceeded to analyze the dynamics of sensegiving, sensemaking, and enactment to develop a more general understanding of the role of justicein postmerger integra-

FIGURE 1

Timeline of the Emergence and Evolution of Key Issues in the Merger of Southco and Northco

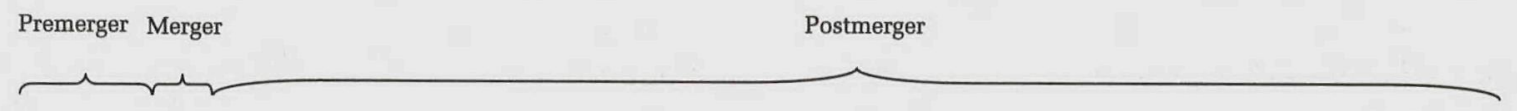

PERIOD 1:

FAIRNESS AS EQUALITY
PERIOD 2:

PERIOD 3

FROM EQUALITY TOWARD EQUTTY DECREASING EMPHASIS ON JUSTICE

\begin{tabular}{|c|c|c|c|c|c|c|c|}
\hline Year 1 & & & & & & & Year 5 \\
\hline $\begin{array}{c}\text { 1. Combination } \\
\text { Model } \\
\text { Organizational } \\
\text { model for the } \\
\text { new group: Top- } \\
\text { management-led } \\
\text { organization- } \\
\text { wide decision }\end{array}$ & $\begin{array}{l}\text { 2. Integration } \\
\text { of Operational } \\
\text { Network } \\
\text { Combination of } \\
\text { operational } \\
\text { networks and } \\
\text { allocation of } \\
\text { responsibilities: } \\
\text { Operational } \\
\text { integration } \\
\text { decision }\end{array}$ & $\begin{array}{c}\text { 3. Allocation of } \\
\text { Resources and } \\
\text { Positions at B-to-B } \\
\text { Decisions } \\
\text { concerning the } \\
\text { integration and } \\
\text { future development } \\
\text { of B-to-B: } \\
\text { Operational } \\
\text { integration } \\
\text { decision }\end{array}$ & $\begin{array}{l}\text { 4. Integration } \\
\text { of IT } \\
\text { Activities } \\
\text { Decisions } \\
\text { concerning } \\
\text { responsibilities } \\
\text { and leadership } \\
\text { in IT: } \\
\text { Operational } \\
\text { integration } \\
\text { decision }\end{array}$ & \begin{tabular}{|c|} 
5. New \\
Approach to \\
Integration \\
Strategy to \\
foster integration \\
and create \\
value: Top- \\
management-led \\
organization- \\
wide decision
\end{tabular} & \begin{tabular}{|} 
6. Reallocation \\
of Capacity from \\
Northco to \\
Southco \\
New capacity \\
ordered by \\
Northco \\
eventually went to \\
Southco's fleet: \\
Operational \\
integration decision
\end{tabular} & $\begin{array}{l}\text { 7. Integration } \\
\text { of Sales Offices } \\
\text { Colocation of } \\
\text { Northco and } \\
\text { Southco's offices } \\
\text { and distribution } \\
\text { of managerial } \\
\text { positions: } \\
\text { Operational } \\
\text { integration } \\
\text { decision }\end{array}$ & \begin{tabular}{|} 
8. New \\
Organization \\
Launch of a new \\
organizational \\
model to \\
streamline \\
operations: Top- \\
management-led \\
organization- \\
wide decision
\end{tabular} \\
\hline
\end{tabular}


FIGURE 2

Abductive Analysis: Structure of the Data ${ }^{a}$

PROBLEMATIZATION: Problematizing previous ways of thinking or acting about distributive justice PROBLEMATIZATION: Problematizing previous ways of thinking or acting about distributive justice (Southco-NorthCo CEO at the annual management convention, closing speech): "The principle
of equal representation is no longer necessary. It prevents emergence of a real group culture."

RULE BREAKING: Decisions and actions that challenge explicit or implicit distributive justice rules (Regarding the appointment of country general managers): "It is a good thing that where there is a dominan partner-Southco is much larger in Germany than Northco-to choose the other side ... because you create an awarenes of the integration project. If you don't, then you risk remaining in habitual paths, and that's exactly what you don't want."

PRINCIPLES: Coining of distributive justice principles

(A vice president in the B-to-B division): "The balancing act? It all starts from the original idea: the best of both worlds. The notion of balancing act means this willingness that nobody, at any time, feels he has been eaten by the other."

\section{SYMBOLIZATION: Decisions and actions that symbolize distributive justice}

SYMBOLIZATION: Decisions and actions that symbolize distributive justice
(A marketing manager shows the new Southco-Northco business card): "Luckily, Northco traditionally had its logo (A marketing manager shows the new Southco-Northco business card): "Luckily, Northco traditionally had its logo
in the upper left-hand corner, Southco in the upper right-hand corner. If you put the two together, everybody still finds their logo right where it belongs and neither of the two had to make a concession.... If the logos start to shift, it is like one of the two has become more important than the other."

EXEMPLARY DECISIONS: Concrete decisions used as examples of distributive justice

(Speech by the program director at a Southco management convention): Closing a route has never been an easy decision. .... The strategic plan is based on a fair growth, and that's a real opportunity. Much ink and saliva have been spilled over, notably on the so-called 'Don't Go East' project, but this is the proof of our common will to coordinate our development.

QUANTIFICATION: Distributive justice rules based on calculations

(A vice president in the B-to-B division): "The 60/40 ratio is a compromise. ... Among the 126 leading positions, 70 are Southco and 56 are Northco.... The world is divided into five geographical areas, a Southco director leads in three area and Northco has two directors."

SILENCING: Silencing alternative interpretations of distributive justice

(Southco corporate communication officer): "We avoided the word merger. . . because in people's unconsciousness, merger means absorption and absorption means job destruction."

MARGINALIZATION: Deligitimating dissident voices about distributive justice

(Southco close advisor to Southco-Northco CEO): "This fair and balanced thing is all wrong. This was never mentioned in the president's discourse. Balance relates to calculation and quantification, this is a residual from B-to-B. It has never been used in corporate communication since the signature of the combination."

ACTIVE SUPPORT: Explicit proactive support of norms of distributive justice

(IT manager B-to-B division) : "You always have discussions like this one on volume versus yield. Whereas we believe in volume, Southco focuses more on yield. But keeping in mind the values of trust, respect, and fairness we have learnt from each other. Now, we are both working toward a middle course."

BUY-IN: Acceptance of distributive justice norms

(Southco engineer, maintenance division): "This whole 'fair and balanced' principle is a very good and smart point of departure. It also increases trust among employees of both companies."

REASONED AGREEMENT: Mixed feelings about the issue but understanding for the distributive justice norm (Northco salesman): "Southco left its business to Northco in some places. It means that they rely on Northco for certain areas. This is the opposite of what happened in another place-though we had been there for 70 years, a very long period. They made their decisions, of course it is cost culting, but that's fine."

OPPOSTIION: Resistance in action against a distributive justice norm

(Northco IT developer): "The majority of IT applications went to Southco. But we have systems that could be (Northco IT developer): "The majority of IT applications went to Southco. But we have systems that could be
worthwhile for the combination. Believe me they are ten years behind compared to us. So call me stubborn but I have decided that we build part of our systems into those of Southco."

DISAGREEMENT: Expression of deviant views regarding distributive justice

(Northco manager on his own management): "What I think is shocking, and I would like to mention it, is that Northco top managers have continued to state that we would collaborate. At the end we have been taken over If I talked about collaboration at some party, everybody would laugh at me. I thought it was collaboration, but we really have been taken over."

\section{QUESTIONING: Raising questions about distributive justice}

(Northco manager): “What is 'fairness' and 'balance? Is it: we are small and they are big, so by what percentage? Is it proportional? .. . Or should you have more VPs of Southco? Or should they have a stronger say? ... What will happen if Southco gets into trouble? Will they kick out a number of our (Northco) people because that is easier
to do?"

IRONY: Conveying a meaning opposite of the literal meaning of a distributive justice norm

(Area manager B-to-B division): "They (Southco) are brilliant strategists. Apparently they are far better instructed in terms of 'how to deal with Northco' than we are instructed in 'how to deal with Southco'."
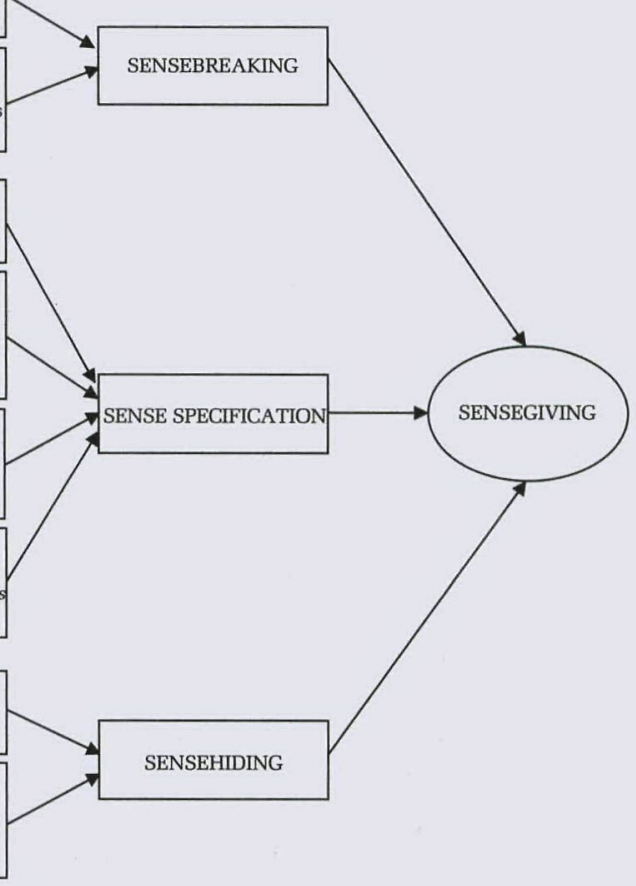

\section{CYNICISM: Expressing distrust and negativity regarding a distributive justice norm}

(Northco manager): "My view is that the big shareholder always decides. That's the reality. Maybe some things

of how we work are adapted, but the really important decisions are taken by Southco. The real decisions are not of how we work are
being taken by us."

${ }^{\mathrm{a}}$ Italic indicates illustrative phrases. 
tion. We first focused on the general pattern revealed by our case: Equality was the central norm during the first period; then there was a shift from equality to equity; and finally the role of distributive justice became less accentuated. We then concentrated on explaining this pattern by identifying key dynamics; specifically, we developed theoretically grounded explanatory mechanisms based on the data (Langley \& Tsoukas, 2010; Van de Ven \& Poole, 1995) to understand this pattern in M\&As more generally. This process led to the development of a more general model of norms of justice as rules of the game in postmerger integration that was based on the dialectics of value creation versus sociopolitical concerns, the dialogical dynamics of sensegiving and sensemaking, and the enactment of norms of justice. As for enactment, we focused special attention on the shifts in the dominant norms of justice, the ambiguity around the norms of justice (the degree to which norms could be interpreted in different ways), and the overall alignment (between managers' and members' views).

This kind of qualitative process analysis involves methodological challenges related to validity and generalizability. Our regular feedback meetings with both companies helped to validate our findings. The corporate representatives could deepen our understanding of specific issues with additional background information and put our findings into perspective. This kind of analysis is necessarily subjective; however, working in an international team, in which we represented the nationalities of the two merging companies as well as other nationalities, helped us to reduce ethnocentricity. Finally, all this analysis was challenging language-wise, as we had to work in the languages of the two countries of origin and also in English. The actual analysis was conducted in the original language, but the main results were translated into English.

\section{GIVING SENSE TO AND MAKING SENSE OF JUSTICE AT SOUTHCO-NORTHCO}

The following sections summarize key patterns in giving sense to and making sense of norms of justice over three time periods (see Figure 1). In each period, we first elaborate on integration pressures, then focus on sensegiving and sensemaking around specific integration issues, and finally discuss the enactment of norms of justice.

\section{Period 1: Equality as the Guiding Principle}

Integration pressures: Value creation vs. sociopolitical concerns. In the following, we examine pressure for value creation and sociopolitical con- cerns and explain how top management tended to emphasize sociopolitical concerns. As for value creation, a key reason for the merger was the synergy potential it offered in a sector that was undergoing market liberalization. A top manager put it as follows at the announcement of the merger: "The single European market reinforces the need for consolidation of the industry." The chief operating officer (COO) of Southco was blunt in a published interview: "The [industry] landscape is moving fast. There are no other options: either we go ahead or we allow ourselves to be suffocated." According to this logic, the merger would be a means to exploit the opportunities of market liberalization and a way to create competitive advantage. In particular, ambitious ideas about significant synergy coming from cost savings were expressed: "We could have said 800-900 million euros, and we could have justified it, but with $\mathbf{5 0 0}$ million euros we are sure we can implement it" (joint statement of the two CEOs, professional press). ${ }^{5}$

At the same time, the merger was sociopolitically challenging. In particular, Southco and Northco had strong national stakeholders and, as organizations, were characterized by strong national identification. Concerns about a loss of autonomy and standing were at the forefront, shown for example in numerous negotiations between the stakeholders. As the CEO of Northco put it, "Northco is a [firm] with a great history and people were afraid that we would be kind of gobbled up and disappear in the merger" (Northco CEO, in the business press, one year into the merger). Furthermore, key employee groups and unions on both sides feared that the merger would result in redundancies or decrease the power of the unions, and these concerns were voiced widely.

This led top management to focus special attention on winning the support of key stakeholders. In particular, the negotiations before the deal and after the announcement were characterized by a focus on the balance of power between the two parties and discussions about ensuring that the interests of both sides would be protected. This led to a prioritization of sociopolitical concerns, even if it meant sacrificing some of the potential synergy benefits. As the two CEOs put it in a joint statement: "We haven't taken full integration of both organizations into consideration. There is further potential, but we are deliberately not looking at it. Many mergers fail because the integration takes place very

\footnotetext{
5 To maintain case anonymity, we do not formally cite some sources. Please contact us for more information about the emperical material.
} 
quickly, and then it turns out it doesn't work. We will not integrate for the sake of integration. If there is a risk of failure, we will not do it" (professional press). Thus, top management took a cautious approach to integration, trying to begin with those areas that would create the fewest sociopolitical concerns. Southco's CEO put it as follows at an important management convention: "Whether experts like it or not, Southco-Northco has chosen its rhythm, one of a pacified firm fully aware of the issues, which has succeeded-results speak-in achieving difficult and ambitious projects." Thus, top management pursued a balance-of-power approach that was subsequently crystallized in the fairness principle, as explained below.

Issues of justice. We now focus on giving sense to and making sense of justice in the context of four issues. We start with top management's sensegiving around the creation of an organizational model that would be acceptable to most stakeholders. We then move on to three central issues of operational integration that highlight middle management's role in providing meaning to issues of justice: the integration of operational networks, the allocation of resources and positions at the "business-to-business" (B-to-B) division, and the integration of information technology activities. Although our text highlights the processual dynamics, Table 2 provides detailed examples of the characteristic modes of sensegiving and sensemaking about justice during this first period.

Issue 1-Combination model: Sensegiving. For top management, the most important issue in the beginning was to find a way to set up a new organization. As explained above, top management needed to create value and at the same time justify the changes vis-à-vis stakeholders who were concerned about any changes that would threaten jobs. To be able to convince stakeholders on both sides that their interests would be protected, top executives focused on fairness as the guiding principle from the earliest stage of the discussions. Most importantly, during the last stretch of the negotiations, representatives of Southco and Northco crafted a detailed document, the agreement on integration rules between Southco and Northco, that spelled out the governance principles for the combination and the rules of the game for subsequent integration. A central theme of this agreement was the "fairness principle," which stressed equality between the two parties. It was guaranteed that the name of the new group (the combined entity) would be Southco-Northco, that the brands and logos of both corporations would be preserved, and that investment in both operational centers would continue.
This fairness principle was then communicated to important stakeholders. For example, Southco's CEO made a significant speech at Northco's works council, stating that "we want to reinforce mutual respect by applying in all areas of the collaboration the principle of fairness." Most top management communications emphasized collaboration on the basis of equality: equal representation on a top management committee and, more generally, equal opportunities for Southco and Northco employees and an equivalent number of Southco and Northco managers in key positions. At this stage, the norm of equality was communicated not only verbally, but also nonverbally, and in particular in the demeanor of the two top managers at meetings and conventions. A Northco technical employee referred to "the way I see [the CEOs of Northco and Southco] together, the way they stand next to each other in complete equality." Importantly, it was agreed on and emphasized that the arrangement should not be seen as a full-fledged merger. A Southco executive vice president (EVP) described top management's reasoning: 'The word 'merger' was forbidden from the very beginning as it connoted ideas of massive lay-offs, hostility, asymmetry in power, and all these negative ideas." A senior manager of communication recalled that "during the early months, we kept calling the journalists to ask them to correct their articles each time they talked of the combination as a merger."

Sensemaking. This approach helped create positive responses from most stakeholders. The idea of equality was especially important for the stakeholders of Northco, who had been very concerned about a loss of identity and relative independence. In that respect, the proposition by the CEO of Southco to christen the new group with the names of the two firms-as opposed to giving symbolic dominance to Southco-had a positive reception. Nevertheless, the Northco works council expressed its careful vigilance right after the announcement of the deal: "Issues that need to be watched closely are the agreements that have been made during the negotiations before the merger. These are specifically the 'fair and balanced' allocation of work and the allocation of 'centers of excellence."' The combination model was also supported by the Southco unions, which were afraid of the job losses that would result from a more radical restructuring. Internally, most lower managers and employees at Southco expressed their satisfaction. Even if some Southco managers thought that the explicit emphasis on equality favored Northco far too much, this view was rarely expressed openly. These primarily positive views pavedthe way for the subsequent 


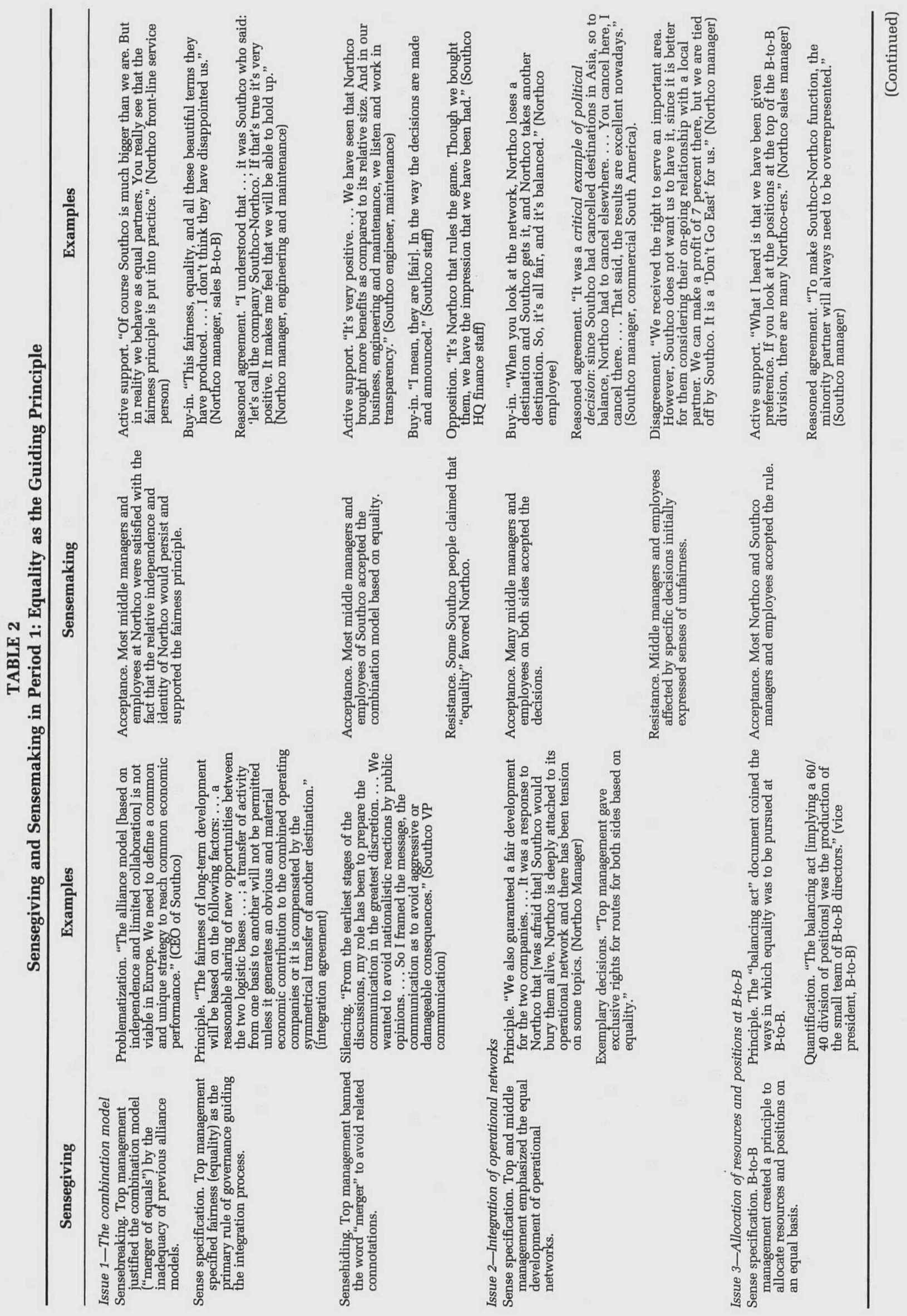




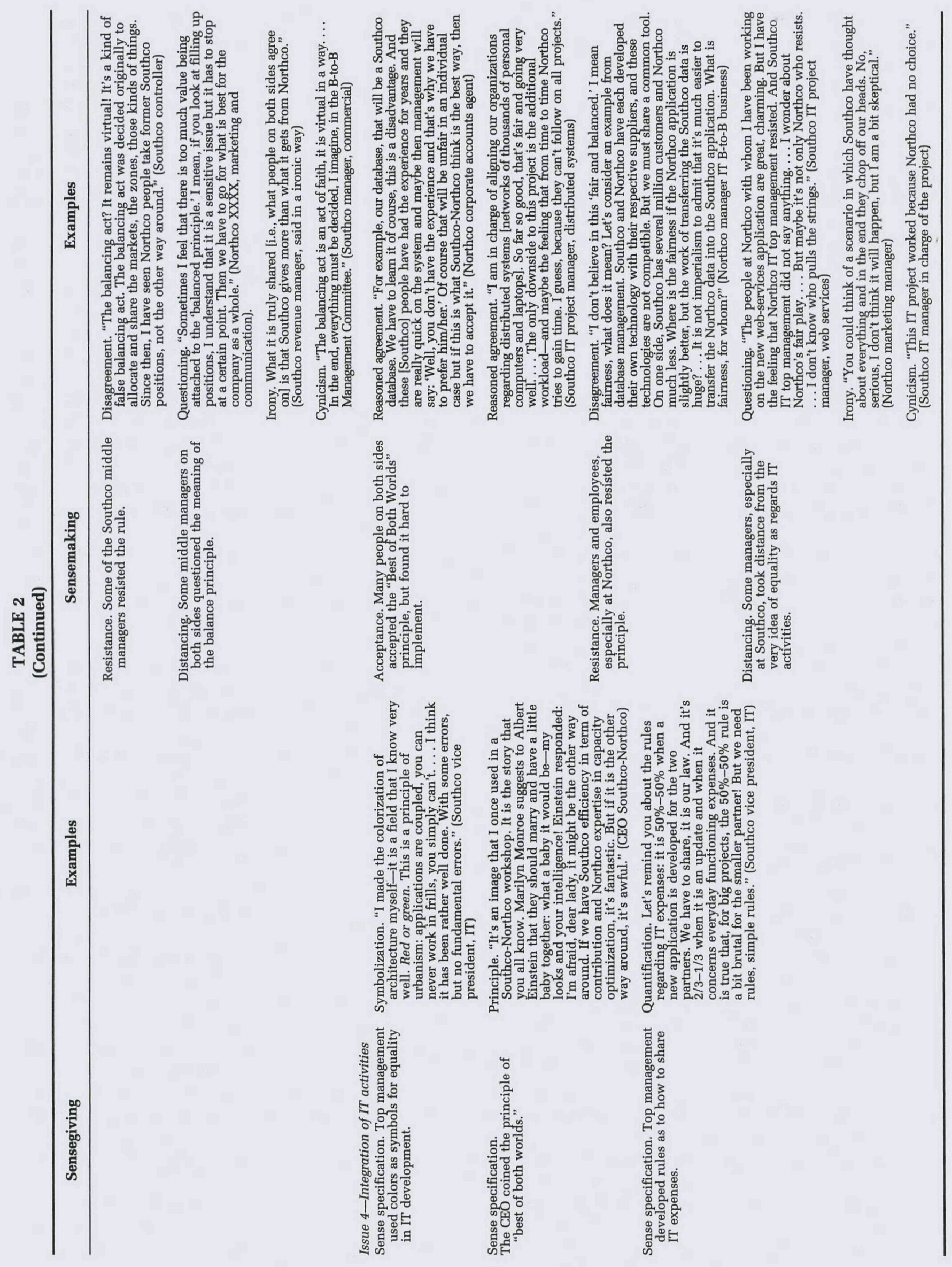


application of the norm of equality in issues of operational integration.

Issue 2-Integration of networks: Sensegiving. In operational integration, top and middle management focused on the specification of the rules of integration, in particular on the meaning of equality in context. The first major issue of operational integration was the combination of networks. The initial agreement on integration rules provided the basis for integration. However, the agreement did not specify how to deal with practical decisions concerning the networks. The first practical decisions dealt with cases of overlapping routes. For example, both companies served two important southern areas. It was decided that Northco would take charge of the first destination, while Southco would take care of the second one. The second decision regarded an important eastern area. At the time of the merger, Southco operated this destination through a local partner. Northco had been planning to serve this destination even before the merger but now was forbidden to do so because this would thwart Southco's local collaboration. Sensegiving focused on justifying these exemplary decisions and on underlining the importance of equality for both companies; integration would provide advantages in making otherwise marginal routes attractive but also required passing some routes on to the other side.

Sensemaking. The decisions on network integration triggered different responses on the two sides. The first decision concerning the southern destination passed almost unnoticed by people at Northco, but it was crucial for the Southco personnel, who saw it as unfair, since the first destination was considered a lucrative one. Among Southco employees, this decision became a widely shared example of the problems of the fairness principle in action. Similarly, the decision about the eastern destination led to resentment among Northco network planners. A Southco vice president in charge of planning explained it as follows: "For years, we have had a special cooperation with our local partner. When Northco told us they wished to extend their operations there, we told them that it was impossible. And it became a kind of sketch: don't go east. They have had a hard time digesting it. They keep returning to us to say they need to have it." This exemplary decision, though causing relatively little harm to Northco, was rapidly discussed throughout the Northco organization. "Don't go east" became a prevalent slogan among Northco employees, crystallizing the problems of the fairness principle in context. Nevertheless, many if not most lower managers and employees appeared to understand and accept these decisions and the way in which they reflected the general principle of equality in integration. A manager at Northco put it as follows: "We lost [X] but we got back something else. So I think it's all going in a fair and equal way."

Issue 3-Roles and responsibilities at B-to-B: Sensegiving. Integration proceeded most rapidly in the B-to-B division, not least because the brand identity was less important in this business area than in others. After 18 months of coordination, it was decided that the marketing, network, and sales functions would be fully integrated, while operational activities would remain separate. To proceed with integration, the five members of the Joint Bto-B Management Committee were looking for a more concrete framework than the fairness principle and eventually spelled out the idea of "balance." They prepared a written document, the "balancing act," specifying what the overall principle meant. These ideas were developed in the joint committee and provided B-to-B's management a means to give sense to and legitimize integration decisions. In particular, an understanding of the distribution of managerial positions according to a $60 / 40$ principle was spelled out. The $60 / 40$ ratio became a kind of compromise between the pure $50 / 50$ equality (which the dominant partner would not accept) and an 80/20 division based on ownership proportions (which the smaller partner would reject).

Sensemaking. The people on either side interpreted the Balancing Act in somewhat different ways. For the Southco people, the Balancing Act referred specifically to a $60 / 40$ split in managerial positions. For the Northco people, it was the overall principle to be followed in successive decisions, calling for respecting some kind of equality between the two parties. Many lower managers and employees at B-to-B, especially those from Northco, seemed to support this principle. In a typical comment, a Northco employee put it as follows: "I believe the whole fair and balanced principle is outstanding and it is really amazing how they [corporate top management] let us [the business] experience it this way." However, there were also critical voices, especially from Southco. For example, a Southco sales representative put it as follows: "Southco's B-to-B activity is the bride's dowry in the Southco-Northco merger."

Issue 4-Integration of IT: Sensegiving. The integration of information technology (IT) systems was a third major operational challenge for the new group. There were ambitious targets for cost synergies. During the first months of the merger, IT executives grouped the more than one thousand IT applications into coherent clusters of interconnected systems and assigned them colors-red for 
Southco and green for Northco-to symbolically indicate which of the two companies would be in the lead for a particular cluster. Overall, the coloring was supposed to lead to an approximately equal allocation of resources and responsibilities. This coloring was later combined with a principle called the "best of both worlds" announced at an important management convention. The idea here was that IT integration should be built on the best capabilities of both sides. Middle management at Bto-B needed to integrate IT early in the merger and tried to implement the CEO's principle and combine the specific competencies of the two IT systems. As B-to-B IT was colored red, Southco led this process.

Sensemaking. Lower management and employees tended to point to the adverse consequences of the initial coloring, which could imply the substitution of a familiar system by another one. In the B-to-B division, Northco employees especially had major problems with the new rule, and many of them denounced what they saw as domination by Southco. A Southco manager understood this position: "To tell the truth, we underestimated that we made them [Northco] swallow a lot of red. We told them: forget your systems, we'll take Southco's." In practice, the principle of equality, as applied in the coloring and combined with the principle of the best of both worlds, led to a succession of compromises, and B-to-B managers and employees started to question whether this principle could, after all, form the basis for effective and fair decision making.

Enactment: Dominant norm, ambiguity, and alignment. We now focus on the enactment of equality as the dominant norm of justice, make observations about ambiguity and the alignment between management's sensegiving and members' sensemaking, and finally summarize the implications for the following period. The prioritization of sociopolitical concerns over value creation pressures led top management to implement the fairness principle. Central to this principle was the idea of equality between the two sides as the overarching norm of distributive justice that would guide integration decision making and action; this was reflected saliently in the new organization model and equal representation in top management (issue 1). As explained above, the norm of equality took different forms and was interpreted in various ways when the networks were combined (issue 2), when responsibilities and positions at B-to-B were allocated (issue 3), and when IT was integrated (issue 4); however, it continued to serve as the primary principle throughout this first period of integration.
This norm of equality was characterized by inherent ambiguity. Initially, top management's fairness principle appeared to provide a means that was both sufficiently clear and sufficiently flexible to appeal to the central stakeholders. The EVP for human resources at Northco explained: "The definition of 'balanced' is flexible. Of course we sometimes explain it in terms of the proportion and size they [Southco] have in comparison with us [Northco] . . . and if you look at that, it also is accepted." However, as operational integration went forward, increasing specification was needed; this was a special concern for middle managers who had to deal with concrete integration questions and decisions. As a result, there was little ambiguity in the case of overlapping routes but more in the case of allocation of positions at B-to-B. Interestingly, some SouthcoNorthco senior executives thought that B-to-B middle managers went too far with their specifications, especially in quantifying the balance; this kind of specification could be viewed as limiting the options for top management to manage the meaning of fairness. However, the inherent ambiguity became a major problem for those dealing with IT: "The coloring aspect pleased everybody but it did not satisfy anybody. We are very good at that. The higher you come the nicer you are to each other. But as soon as you look at the consequences the house explodes.... At a higher level you can quickly agree, because then it is all still very abstract" (two Northco senior managers).

As the issues demonstrate, there was significant alignment between top and middle management's sensegiving and member sensemaking, especially in the beginning when the fairness principle worked to assure key stakeholders that their interests would be protected. Although there were deviant views on how the integration of networks and the allocation of resources and responsibilities were handled, on the whole the norm of equality provided top management as well as middle management with a way to legitimate integration decision making. However, this became more difficult with IT (issue 4), where the complexity of the issue created increasing doubts whether equality could be reached and whether the principle of equality could serve as an overriding norm in decision making more generally. An IT project manager at Southco put it as follows: "Regarding [project], I didn't tell you everything. We [Southco] did 90 percent of the job and they [Northco] did 10 percent. Everybody knows it. ... I would like that the power relations be more expressed. We respect them too much." 
Alongside these experiences were other indications that the members of the organizations would no longer be able or willing to follow top management's guidelines. This was shown in the increasing use of "the M-word"-merger-at the end of the first period. Whereas in internal and external communication "combination" was the official term (both in English and in the local languages of Southco and Northco), people now started to use the M-word.

Finally, all this amounted to increasing problems in holding on to equality as the guiding principle in postmerger integration management. As a top Northco manager put it, "That fairness, the concept of fairness [implying equality] ... it simply doesn't work. We looked at it in terms of numbers and positions. So if the HR person of [a division] was from [Southco], then the one from the B-to-B division should be from Northco. Well, that's a complicated construction. So what you saw was that if a position changed color [was taken by someone from the other company] that somewhere else you needed to shift color, too." Such reflections paved the way for the change in the following period.

\section{Period 2: Equity as the New Norm of Justice}

Integration pressures: Value creation vs. sociopolitical concerns. We now focus on the mounting pressure for value creation and explain how this led to a new phase in the integration. Top management became increasingly aware of the changes in the environment: "Input materials prices continue to increase and the forecasts for economic growth are oriented downwards, especially in emerging markets" (Southco CEO, at a press conference). This was generally interpreted as a sign that more should be done in terms of synergy realization. A leading strategist put it as follows: "In some areas [tighter] integration is required to encourage optimal synergy realization" (article in the business press). Moreover, integration created its own dynamic. For instance, once sales people started to make combined calls to major customers, the pressure to integrate IT systems increased: "It [the integration] spreads and everybody will have to think in his way about what it will mean in the future" (country manager, Northco).

However, top management was still acutely aware of the sociopolitical concerns and the risks of radical changes. A top manager explained, "The risk would be to speed up the combination process to get a few additional hundred MEUR of synergies, to compensate for the sharp increase in [input] prices, and then the combination that has started well would turn nasty" (VP marketing, Southco).
There was also a new kind of anxiety about integration as people anticipated changes: "There is a very small group who think it's very stressful, who see a threat in [. . . ] the second phase of the integration. That's to be expected" (top manager, purchasing, Northco). This led top management to promote further integration while continuing to emphasize justice. However, justice was no longer seen as overall equality between the two merger parties, but as equity in terms of fairness of specific integration decisions in their proper context, as is illustrated below.

Issues of justice. In the following, we focus on giving sense to and making sense of justice in the case of three issues. We start with top management's new approach to integration. We then move on to two central issues of operational integration that highlight both top and middle management's roles in promoting equity: the reallocation of capacity from Northco to Southco and the integration of sales offices. Table 3 provides detailed examples of the characteristic modes of sensegiving and sensemaking about justice during this second period.

Issue 5-New approach to integration: Sensegiving. For top management, this new situation led to a fundamental change in their approach to integration, which was carefully planned and communicated internally and externally. The Southco CEO used the M-word for the first time officially at an important management convention. At the same time, he also problematized the prevailing interpretation of fairness as equality and called for new thinking based on equity. At the next management convention, he went a step further and explicitly stated that "fairness will gradually be replaced by skills." In a similar vein, top managers at Northco progressively abandoned references to equality and balance that were initially crucial vis-à-vis their stakeholders and went as far as publicly acknowledging (in the internal newsletter) that the norm of justice based on equality "had not been very unambiguous." Eventually the new CEO of Northco put it as follows in an interview with a business magazine: "Instead of 50/50 we now have 7 members from Southco and 6 from Northco [in the top management team]. I think that is right, given that Southco is twice as big as we are." This indicates that although equality in absolute terms was no longer emphasized, a certain degree of proportionality was still important.

Sensemaking. Reactions varied among the personnel. Most of the Southco lower managers and employees seemed to accept and eventually support the new approach to integration. However, feelings at Northco were mixed, and some expressed resistance. At Northco, a marketing man- 


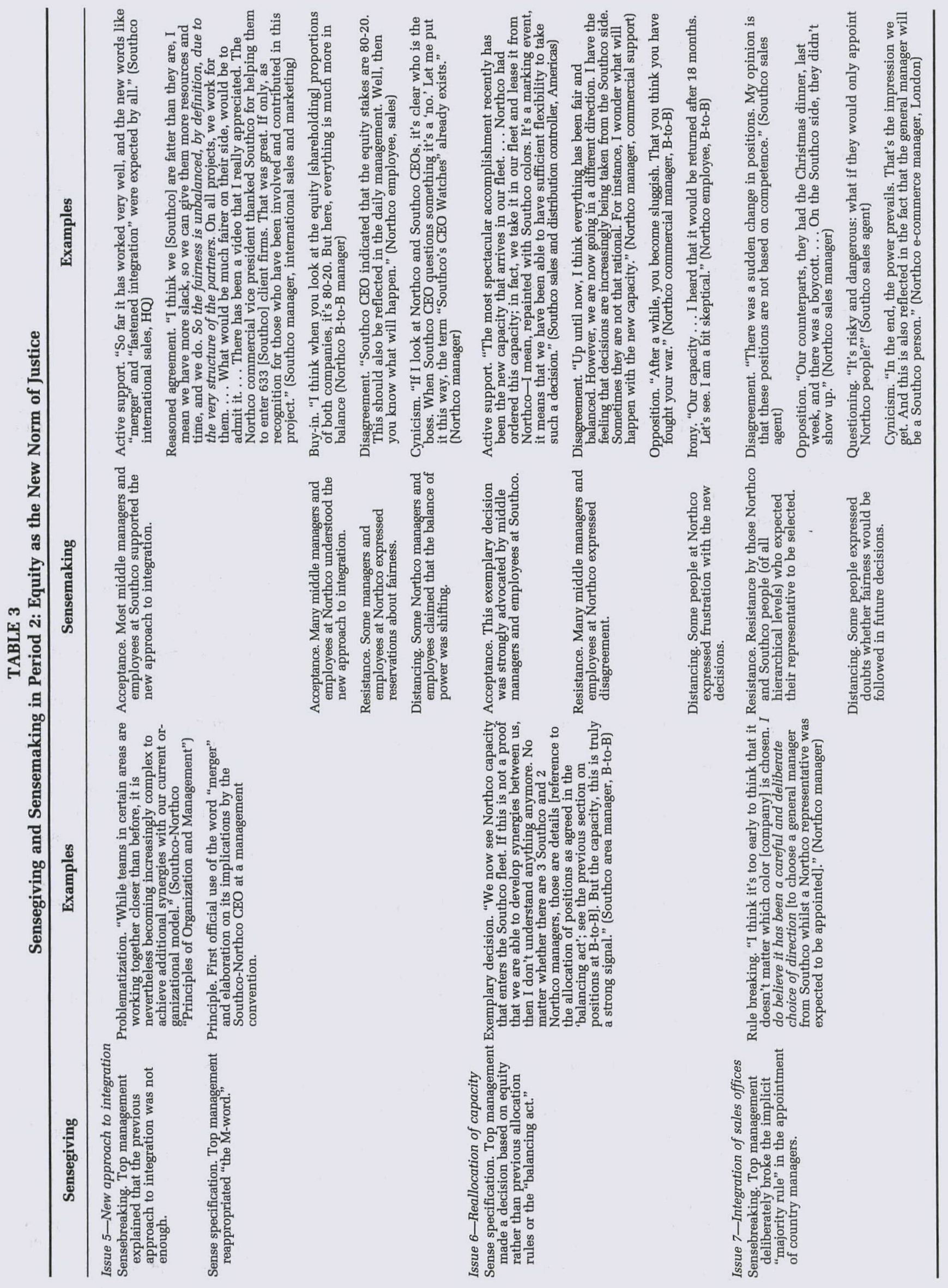


ager put it as follows: "This year you could see for the first time that the power relationships are moving in the direction of Southco. This is for example reflected in the new top management team. There is no balance anymore." An IT manager at Northco said: "In the first years we had a honeymoon feeling. You now see that the focus on equality is crumbling off. It will have its effects on ownership and employment in both organizations." This kind of discussion was also carried on when dealing with operational integration, as illustrated below.

Issue 6-Reallocation of capacity: Sensegiving. As to operational integration, an important event took place in the B-to-B division. Years before, Northco had made a decision to invest in new operational capacity. It was, however, decided that this capacity would not be used to expand the Northco B-to-B fleet but would be transferred to Southco. Top management justified this exemplary decision by explaining that this capacity would contribute more to overall results if put at work at Southco. In this instance, top management moved away from equality and instead emphasized that decisions should be made on the basis of what was needed to gain expected returns. By doing so, top management abandoned the earlier sense of fairness, which had been defined exclusively as equality, and opened the door to a more complex meaning of justice. As the new capacity would pay off more for the merger group if used at Southco, the decision put equity to the fore.

Sensemaking. Responses to the reallocation of capacity from Northco to Southco were very different on the two sides. This decision was very much welcomed by the Southco employees, some of whom had been dissatisfied with the way Northco "had received favorable treatment" (see the former period). However, not all people on the Northco side appreciated this eminently symbolic decision. A Northco manager put it this way: "An example that clearly shows everything is going a bit more into the direction of Southco is the new capacity that we are giving to Southco. It's our investment."

Issue 7-Sales offices: Sensegiving. Sales offices were another key area of operational integration. Here, the purpose was to combine Southco and Northco offices and rationalize sales and marketing processes in specific countries. Although this integration was announced soon after the merger, it was not fully brought into effect until the second period. We studied the integration of sales offices in the six largest European countries. Although three of the countries were clearly dominated by Northco from a commercial perspective, the other three cases were just as clearly Southco's turf. Integration of the sales offices implied a reduction in the number of managerial positions and was therefore watched closely. In appointments, it had been initially agreed that the general manager would come from the locally commercially dominant firm and the second in command would come from the other party. According to this "majority rule," the distribution of general management positions was roughly proportional to the local market positions of the two companies, and the rule that the second in command should come from the other company served to maintain balance; hence the majority rule can be seen as a manifestation of equality. This rule was applied as expected in the first four countries. However, decisions regarding the fifth and sixth country broke the rule. A Southco person (not a Northco one, as the rule called for) was appointed in the fifth case, and a Northco manager (not a Southco one, as the rule implied) in the sixth one. Thus, the norm of equality was replaced by equity in the sense that the managers who were deemed more competent or otherwise more suitable from top management's perspective were chosen for these positions regardless of which side they came from.

Sensemaking. The breaking of the majority rule triggered mixed responses in the merged organization. Initially, people were caught by surprise. For example, a Northco manager reacted as follows: "What happened in [the fifth case] is a strange move, given the logic of the picture. People will certainly question that." Similarly, people on the Southco side were astonished by the decision in the sixth case. However, after these initial reactions, many lower managers and employees showed understanding for the need to "proceed further with integration" and to focus on "situation-specific considerations."

Enactment: Dominant norm, ambiguity, and alignment. We now explain how equity was enacted as the dominant norms of justice and discuss ambiguity and alignment as well the implications for the following period. The increasing focus on value creation triggered a change in that top management pursued a new approach to integration that involved a shift from an explicit emphasis on equality between the merger parties to equity in relation to the two parties' contributions (issue 5). In a nutshell, the new principle was to allocate resources according to what the two parties deserved. This norm was enacted in the subsequent operational integration issues exemplified by the reallocation of capacity (issue 6) and the integration of sales offices (issue 7), although the interpretations of the new norm varied a great deal. The decision regarding the reallocation of capacity be- 
came a symbol of the new approach, but the norm itself was perceived differently by the two parties. Interestingly, it was generally thought that breaking the majority rule in the integration of the sales offices was a means for top management to increase awareness about the importance of situation-specific considerations when making integration decisions.

Initially, the focus on equity seemed to reduce the ambiguity regarding equality. Not only top managers but also many lower managers and employees from both sides recognized that equity reduced the ambiguity around equality: "It's difficult to say that both our growth rates should be equal. You see that you get frictions [with that norm]. I expect that this decision [that equality would no longer be the guiding principle] will change things in the future" (manager, communication, Southco). However, later on awareness of the ambiguity around equity arose: "They now more often use the slogan 'fair share.' And yes, 'fair share' can be expressed in different ways. If you look at the contribution to profits, it should be 50-50. But if you have a board of 13 people, and it's 5 against 8 " (manager, network planning, Northco). This ambiguity related to equity became increasingly salient when people reflected on the reallocation of capacity and grew even more so with the breaking of the majority rule. Thus, again concrete integration issues revealed problems in applying the norm promoted by top management.

Although dissident voices could be heard, top and middle management's sensegiving and member sensemaking about the new approach to integration and its implications for justice remained significantly aligned. However, in concrete decisions concerning the reallocation of capacity and sales offices, misalignment also emerged. This was most evident in increasing resistance and distancing on Northco's side: "I understood the first move [appointment of country managers] is a political one. But I hope in the second run we will look for the best people" (sales manager, Northco).

Given all this, top management started to sense that there was again a need for change. A middle manager at Northco put it as follows: "I would prefer if they would not even consider where someone comes from, but purely which person with what qualities comes at what position. Everybody is ready to go to the next phase. And most people say it is about time to start doing it like that." This paved the way for a focus on efficiency in the following period: "What we do most-and more and more-is to look through a 'group lens' at the impact of a change we want to make. . . . If we want to add a new destination and Southco wants to do the same, you can say 'We were the first, so we will do it.' No, you need to look at that from a group, a Southco-Northco perspective. And that's happening more and more" (director, network planning, Northco).

\section{Period 3: Decreasing Emphasis on Distributive Justice}

Integration pressures: Value creation vs. sociopolitical concerns. We will now explain how the pressure for value creation increased and overrode sociopolitical concerns, leading to a pronounced focus on efficiency above everything else in the third period. This period was characterized by major financial challenges due to external economic shocks. These shocks hit the whole industry and were widely publicized: "Profits plunge under pressure from volatile [input] prices and falling demand" (newspaper article on Southco-Northco's industry). This led Southco to make a loss, and the group showed only a very small profit. All this increased pressure to create synergy, in particular in terms of more direct cost savings: "From next fiscal year on, the cost synergies must take over from revenue synergies, notably in two fields [IT and procurement] that require a special attention" (EVP finance, Southco).

The sociopolitical concerns related to the relationship between the merger parties became less central. A country manager put it as follows: "[The Southco CEO] has defined it fantastically: five years of peace, no forced layoffs, buys you time.... It's a very well proceeding collaboration in that way, in all peace and without tumbling over each other. ... But I see that the cracks can come into the building if you don't give sufficient support to your collaboration. For instance, when sales people in my team are in the market and have to learn by heart two completely different policies and use that in a sales talk, wait a minute, there is something wrong." Thus, top management reasoned that they needed focus on efficiency, even if it meant relegating concerns about the relationships between the two parties to the background. This was reflected in a matter-of-fact referral to the efficiency principle by a Southco manager who acted as a liaison between the two companies: "Of course those decisions regarding ... the integration of the purchasing and supply departments are based on cost savings!"

Issue of justice. In the following, we will focus on the most important integration issue during this period, the launching of the new organization by top management, with accompanying changes in the norms of justice. Table 4 provides detailed ex- 


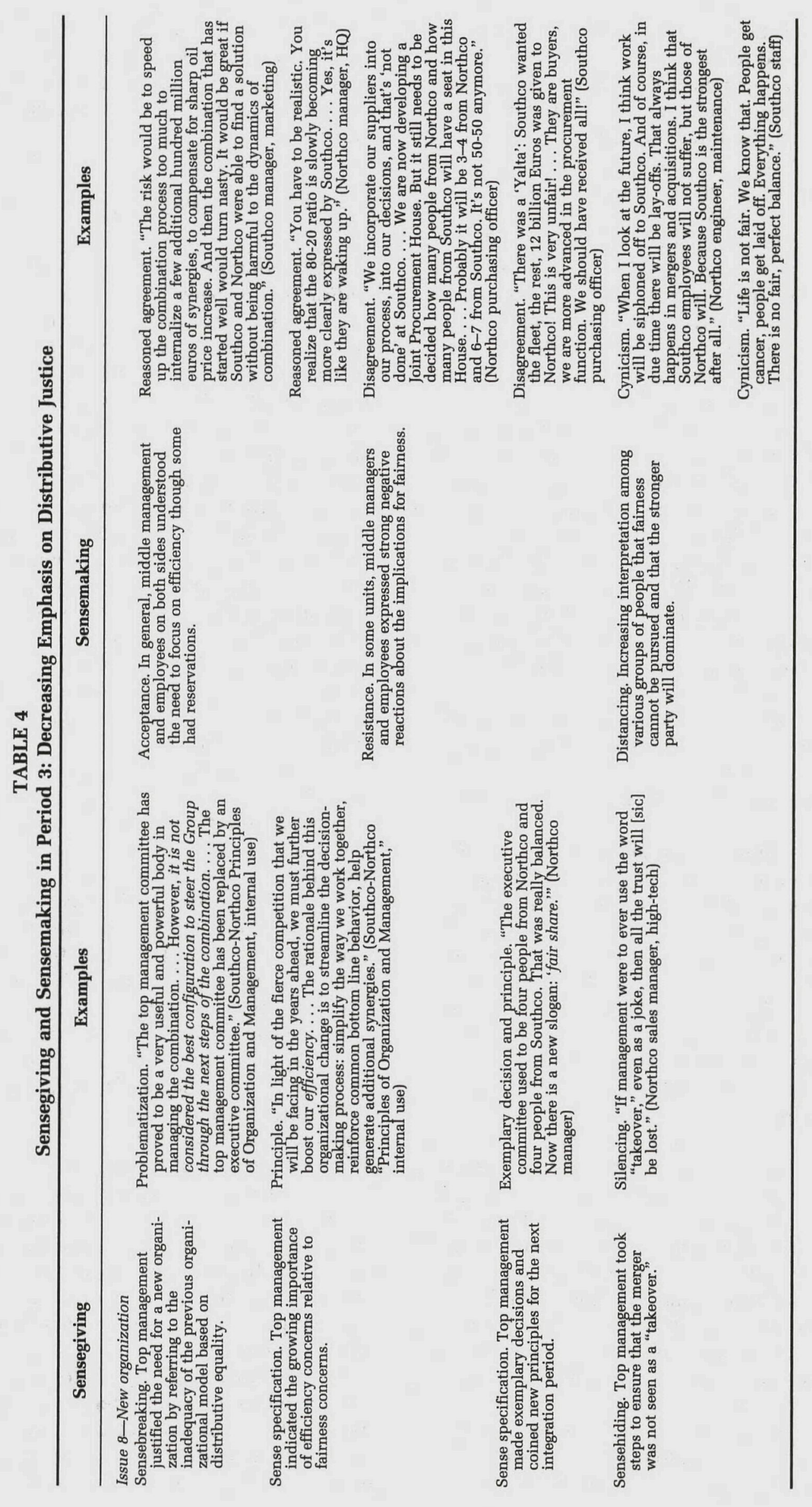


amples of the characteristic modes of sensegiving and sensemaking about justice during this period.

Issue 8-The new organization: Sensegiving. Top management launched a new organization structure as a way to improve efficiency in general and to reap synergy benefits in particular. The new organization-based on integrated functions and activities-was communicated in various arenas to important internal and external stakeholders. In particular, top management explained the new approach at an important management convention. All convention participants received a booklet entitled "Southco-Northco Organization and Management" that provided the new principles of organization with reference to an update of the integration agreement: "The Integration Agreement now gives us the opportunity to reshape the governance and organization of the Group as the 3-yearinitial period ends." The central message was clear: "In all decision-making, the Group must focus on what will optimize the interests of SouthcoNorthco and the common bottom line." This document cascaded through the organizational layers and served as a practical reference regarding functional integration. It is noteworthy that any direct reference to equality had disappeared. Fairness was still mentioned a few times, but more as a general aim of equity rather than as a specified principle. The message was clearly that efficiency concerns were to be given a much more prominent role than distributive justice in guiding the integration process. Subsequent communication followed this pattern; for example, the Southco CEO was quoted in the Northco company newsletter as follows: "Within the new organization, cooperation with each other is based on mutual dialogue, looking for consensus and fairness." This did not, however, mark an end to the management of meaning. Significantly, top and higher management continued to avoid any reference to "acquisition," "dominance" by either party, or other images of an imbalance in power. This was considered extremely important, as top management was very concerned about any interpretations that would trigger internal politics.

Sensemaking. It seemed that people throughout the organization understood the need to focus on efficiency. However, lower managers and organization members also expressed dissatisfaction with specific decisions that were not favorable from their perspective. Moreover, some people now appeared to be taking more distance from justice. An increasing number of people from both companies started to question whether any norm of justice could work as an overall governing principle. Eventually, most of these critics came to share a com- mon sentiment: power would eventually prevail, and Southco would dominate: "I think more and more will be coming from [Southco's head office], that development is already visible. The big jumps are made over there. I think that makes sense. If you buy a company you want to be the one deciding what to do with it" (country manager, Northco).

Enactment: Dominant norm, ambiguity, and alignment. We conclude by explaining how norms of justice received less attention than before and by making specific comments about ambiguity and alignment. As illustrated above, pressures to achieve efficiency prevailed over sociopolitical concerns in this period. This led top management to launch a new organization model that radically changed the approach to integration. Because efficiency was emphasized, distributive justice received less attention. As a HR manager at Northco put it: "I always distinguish between three phases in this collaboration. The first phase is characterized by coordination, the second phase . . . by combination, and the third phase will be characterized by integration. And with integration the notion of fair and balanced will disappear. What you do then is creating organizational unity. And well, within an organizational unit fair and balanced is not really a theme anymore." Now any references to justice related to equity; merit and competence served as the bases for integration.

As distributive justice received less attention, it remained ambiguous. This provided top management with increasing latitude in its decisions and actions. However, any decisions had to be justified in context, as the previous principles and rules related to fairness no longer applied per se: "A merger is a tsunami. It will progress whatever happens. You never resist. You learn to swim" (top manager, Southco). Finally, as noted above, people seemed to align with the new principles promoted by top management. At the same time, there was an increasing disillusionment over the ability of any principle to serve as an overarching norm for postmerger integration.

\section{THE ROLE OF JUSTICE IN POSTMERGER INTEGRATION: A PROCESS MODEL OF SENSEGIVING AND SENSEMAKING}

The Southco-Northco merger reveals a pattern in which the focus on sensegiving and sensemaking moved from equality to equity to less emphasis on distributive justice. Although this revelatory case has unique features, we argue that the pattern may also characterize other merger cases, especially symbiotic ones (Haspeslagh \& Jemison, 1991). In the following, we develop a process model that 
explains how and why this pattern emerges and facilitates understanding of the dynamics related to justice more generally. First, we focus on the dialectics of value creation versus sociopolitical concerns that drive shifts in norms of justice over time. Second, we concentrate on the dialogical dynamics of sensegiving and sensemaking that explain how exactly norms of justice are socially constructed in a postmerger organization. Third, we conclude by discussing three aspects of the enactment of norms of justice: the dominant norm of justice, the ambiguity around the norms of justice, and the alignment between managers' and members' interpretations of justice. Figure 3 provides a summary of our process model.

\section{Dialectics of Value Creation and Sociopolitical Concerns}

Postmerger integration involves pressures of value creation and sociopolitical concerns. These pressures form a dialectical relationship-that is, they can be seen as opposing forces in organizational change processes (Van de Ven \& Poole, 1995). Previous studies on interorganizational forms have pointed to a central dialectic of efficiency and equity (Ring \& Van de Ven, 1994), and our analysis adds to this research by demonstrating how the dialectic of value creation versus sociopolitical concerns drives shifts in norms of justice.
This becomes salient when we observe the shifting emphases placed on the two sets of concerns over the three time periods studied.

As our case illustrates, symbiotic mergers involve difficult sociopolitical challenges; dealing with them has priority at the beginning of postmerger integration. These pressures often imply a special need to make sure that both sides are, in practical and symbolic terms, treated as equals, leading to equality as the prevalent norm of justice. However, this focus may undermine realization of the full synergy potential. This was the case in Southco-Northco throughout the first years of integration, when top management pursued a cautious approach.

Over time, however, it becomes difficult to retain this focus on equality as the dominant norm of justice. Pressure to create value tends to accumulate in the course of an integration. As our case shows, external changes in the business environment may significantly add to this pressure. Internally, equality may be difficult to maintain when people continuously compare the standing of the two partners (Hambrick \& Cannella, 1993); our case provides abundant evidence of this. Moreover, preoccupation with equality tends to reproduce overt or covert conflicts between the two partners (which is why Larsson [1990] developed his "equality/conflict" approach). As a result of these external and internal pressures, the focus tends to shift toward equity as an overall norm of justice.

FIGURE 3

\section{The Role of Justice in Postmerger Integration: A Dynamic Model of Sensegiving and Sensemaking}

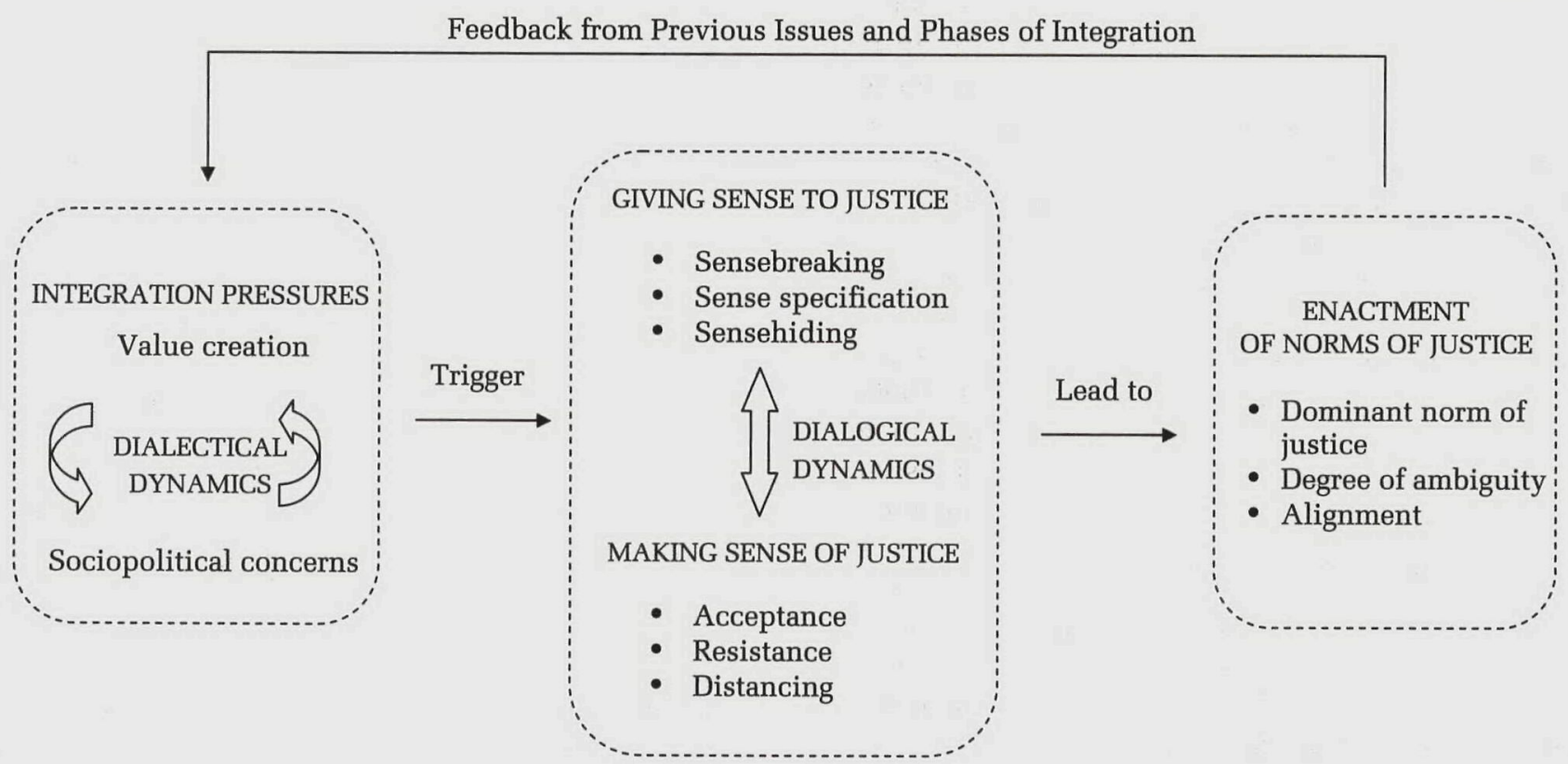


Finally, as integration proceeds, the need to focus explicit attention on justice in terms of the distribution of roles, responsibilities, and cutbacks between the two merger parties decreases. Thus, over time a need arises to move from distributive bargaining to value creation through integrative bargaining (Walton \& McKersie, 1965). Organizational changes also become less directly associated with postmerger integration with time, which further reduces the need to concentrate special attention on distributive justice. This was the case in Southco-Northco at the end of the third period. The dialectics of value creation and sociopolitical concerns thus explain why there is a tendency to move from equality to equity to less attention to distributive justice in postmerger integration. However, this explanation is not sufficient to understand how exactly norms of justice are socially constructed-hence the need arises to examine the dialogical dynamics of sensegiving and sensemaking in more depth.

\section{Dialogical Dynamics of Sensegiving and Sensemaking}

Justice is given sense to and made sense of in dialogical processes (Boje, 2008; Tsoukas, 2009). In its simplest form, "dialogicality" implies a dialogue between the sensegiving of change agents and the sensemaking of change recipients (Bartunek et al., 2006; Stensaker \& Falkenberg, 2007). However, this dialogue goes beyond direct social interaction because managers' sensegiving already presupposes and takes into account members' sensemaking and vice versa (Sonenshein, 2010).

Sensegiving. Our case elucidates how managers' purposeful sensegiving contributes to the social construction of the rules of the game in unfolding postmerger processes. Specifically, acts of sensebreaking, sense specification, and sensehiding steer the course of integration and the social construction of norms of justice. The analysis demonstrates the crucial role of sensebreaking as a means to uproot previously established norms of justice and to prompt a focus on new meanings. Analyses of sensebreaking have highlighted its importance elsewhere (Maitlis \& Lawrence, 2007; Pratt, 2000), and Mantere et al. (2012) underscored its role in an M\&A context. Our analysis follows these lines but further clarifies the way in which top management could significantly impact the course of integration through problematization and rule-breaking decisions. In our case, top management's discourses in documents (e.g., the initial agreement on the rules of integration) and in public and private speeches (e.g., at management conventions) paved the way for change. In addition, decisions and actions that broke previously established rules steered the course of integration; this was most apparent in the second period in the case of the integration of sales offices.

Sense specification was ongoing in the course of postmerger integration. There seemed to be a pattern according to which sensebreaking was often followed by a need to give more specific sense to justice. As our summary tables illustrate, this sense specification took different forms, ranging from more abstract coining of principles to exemplary decisions and actions, symbolization, and quantification. This sense specification could at times lead to increasingly shared meanings, while at other times the results were more ambiguous. Both top managers and middle managers engaged in sense specification; this was especially the case in the first period, when middle managers both together with top management and more independently sought to give sense to equality. An example of the latter was the balancing act document crafted by B-to-B management as a means of handling integration on its own turf.

This case also demonstrates the importance of sensehiding (silencing alternative discourses or marginalizing particular voices). Although previous research has hinted at its importance (Vaara \& Monin, 2010), the role of sensehiding has not been systematically examined. This is undoubtedly related to methodological difficulties in examining taboos or the unsaid. Nevertheless, this case provides ample evidence of the importance of deliberate and systematic sensehiding. For example, top management focused extensively on "equality" and "balance" during the first years but deliberately avoided using the term "merger." Later "fairness" was linked more with equity, and "the M-word" was reappropriated, but terms such as "takeover" remained taboo. This dynamic has a major impact on the vocabulary through which people are supposed to give sense of issues at hand, with constraining and enabling implications.

Sensemaking. Member sensemaking plays a crucial role and determines whether norms of justice are ultimately enacted. Our analysis highlights the various ways in which acceptance of the norms, resistance to these norms, or taking distance from them affected the course of postmerger integration. As could be expected from previous studies (e.g., Marmenout, 2010), people's reactions often varied according to their organizational membership, but at times divides cut across the organizational boundaries. Thus, our study indicates that organizational sensemaking in postmerger integration is characterized by polyphony (Sonenshein, 2010) 
and ambivalence (Piderit, 2000) rather than by straightforward compliance or resistance.

In many instances, the members of the organizations tended to accept the rules of the game articulated by management. This could mean active support or less active buy-in. In addition, people expressed reasoned agreement, or mixed feelings about the issue at hand, but understanding for the underlying norms of justice. This was the case for example with the Southco people who were unhappy about the disproportionate influence of Northco but nevertheless accepted a partial "reverse takeover." This observation underlines the importance of examining not only people's perceptions of justice-the traditional focus of organizational behavior scholarship-but also their interpretations of the underlying norms.

At times, people resisted the decisions and/or the underlying norms proposed. This resistance could be expressed more or less openly depending on the issue at hand. Frequently, especially those in managerial or expert positions could voice their concerns in disagreement. But our analysis also revealed active opposition, in how pockets of more active resistance emerged among specific groups of people. In our case, examples of strong resistance were rare, but more of them are likely to be found in more controversial or less carefully managed M\&As. Moreover, it is to be expected that selfcensorship represses reporting of active resistance in interviews.

In addition to open resistance, organization members distanced themselves from norms proposed by management, for example by questioning the operationalization of norms or by expressing irony or cynicism. In fact, such distancing became more common toward the end of the observation period. For example, some people started to frame integration management more as a "game" or even pointed to the hypocrisy of management if the decisions and actions did not seem to follow managerial discourse about fairness. This can be interpreted as a sign that the management of the shift from equality to equity did not completely succeed or, more generally, as an indication that it is very difficult to live up to the norms of equality in postmerger organizations. However, it can also be seen as dissatisfaction that paved the way for the decreasing emphasis on distributive justice.

\section{Enactment of Norms of Justice}

These dialogical sensegiving and sensemaking processes lead to the enactment of norms of justice. Our model elucidates three aspects of the enactment of norms of justice: the dominant norm of justice, the ambiguity around the norms of justice, and the alignment between managers' and members' interpretations of justice.

Dominant norm of justice (equality/equity). Our case analysis shows how norms of justice emerge from a myriad of sensegiving and sensemaking acts. Thus, rather than casting norms of justice as universal reference points, our model helps to explain how they may be complex, ambiguous, and contested at any point of time. Nevertheless, our analysis clearly demonstrates an overall pattern in which, over time, the dominant norm is first equality; then, equity replaces equality; and finally, the explicit attention given to distributive justice decreases. On the one hand, this involves specific acts of sensebreaking, sense specification, and sensehiding through which the actual meanings of norms are created. In particular, since justice was initially linked inextricably with equality, it needed to be disavowed by sensebreaking when times changed. Subsequently, through sense specification the new norm of equity was given more concrete content, and sensehiding was needed to steer away from other interpretations. On the other hand, the enactment of a new dominant norm of justice is crucially dependent on member sensemaking that may be accepting, resistant, or distancing. In particular, acceptance was needed to enact the new norm of equity, but resistance could undermine some of the organizational implications. Interestingly, examples of distancing can be seen as criticism, but they also pave the way for shifting to another norm of justice.

Ambiguity. Our analysis also helps to explain the role of ambiguity around norms of justice. In particular, our case elucidates the enabling and constraining aspects of ambiguity around norms of justice. By so doing, it adds to previous studies that have explored ambiguity from other perspectives (Denis, Dompierre, Langley, \& Rouleau, 2011; Jemison \& Sitkin, 1986; Risberg, 2001). Our analysis points out that some ambiguity is needed to mobilize stakeholders with different interests and perspectives (Denis et al., 2011). Indeed, most of the principles promoted by top management in our case remained somewhat abstract and subject to interpretation. Interestingly, there is evidence that top management also wanted to retain latitude by not going too far in specifying the norms. By so doing, they also emphasized their role as the ultimate decision makers vis-à-vis middle managers.

There is, however, a need for ambiguity reduction to advance with concerted action in postmerger integration (Clark et al., 2010; Risberg, 2001; Vaara, 2003). In our case, a variety of efforts of sense specification led to situation-specific under- 
standings and rules of thumb. In particular, middle management needed to specify norms in order to deal with concrete issues of integration. Nevertheless, when people are confronted with increasingly challenging issues of integration, it becomes very difficult for them to specify and apply particular norms of justice. This in itself puts pressure on prevailing norms of justice and can ultimately lead to the development or emergence of new norms. This was the case at the end of the first period, when organization members were dealing with IT, and at the end of the second period, when they were struggling with appointments of country managers. Thus, our analysis indicates that norms of justice almost inevitably involve ambiguity and that this ambiguity should not be seen merely as a way to manage meaning to win the support of various stakeholders or as a problem to be solved with increasing specification, but rather should be seen as an inherent feature of postmerger integration that both helps to advance integration and constrains the actions of managers and other members of an organization.

Alignment. Finally, our analysis of sensegiving and sensemaking helps to explain to what extent alignment about norms of justice between and among managers and other organization members. By highlighting the myriad of sensegiving and sensemaking acts, our analysis illustrates the potential for agreement and disagreement that exists around any integration issue. In particular, our case shows how member sensemaking may either support (acceptance) or challenge (resistance or distancing) the attempts of management to manage meaning or steer the course of integration. By so doing, our analysis elucidates the crucial role of norms of justice in the micropolitics of postmerger integration, which has received little attention in previous research (Graebner, 2004; Hambrick \& Cannella, 1993; Vaara, 2003).

Our case demonstrates how, in the beginning of the first and second period, there was significant alignment regarding the norms of justice. In both cases (the combination model and the new approach to integration), organization members mostly accepted the principles proposed by top management, which facilitated further integration. However, over time, with increasingly complex integration issues such as IT or the appointment of country managers, there was less alignment about the specific norms of justice and their application. Thus, the very basis for joint action was undermined, showing in less successful efforts to integrate and paving the way for change. In the third period, top management's decreasing attention to distributive justice met acceptance, as many members understood the need to focus on value creation. Interestingly, the distancing of others (disillusionment about whether any norm could form the basis for future decisions) also contributed to the same outcome. Thus, our case analysis suggests that the decreasing attention to justice in the third period resulted not only from the increasing pressure for value creation, but also from the extended dialogue between the actors. In all, alignment between sensegiving and sensemaking around a norm of justice is a two-edged sword: perfect alignment optimizes integration under a given norm, but it makes it very hard to switch to a different norm. The point is that only by examining both managerial sensegiving and member sensemaking over time can one understand why the promoted norms of justice form a basis with which to proceed with integration or not.

\section{DISCUSSION AND CONCLUSION}

This study elucidates the central role that norms of justice in general and distributive justice in particular play as rules of the game in postmerger integration. Previous research has acknowledged the importance of justice in postmerger integration (Ellis et al., 2009; Hambrick \& Cannella, 1993; Meyer, 2001; Meyer \& Altenborg, 2007). We have demonstrated that in addition to a focus on perceptions of justice per se, attention should be paid to their temporal dynamics, to how sensegiving and sensemaking about distributive justice impact the course of postmerger integration. We have concentrated on symbiotic (Haspeslagh \& Jemison, 1991) mergers in which distributive justice is accentuated. Although our case has unique features, it reveals three postmerger integration phases that are likely to characterize symbiotic M\&As: first, a period when the emphasis is on equality; then a period when the focus shifts to equity; and finally a period when explicit attention to distributive justice decreases. Thus, our case analysis demonstrates that justice-together with related cultural (Vaara \& Tienari, 2011), identity (Clark et al., 2010; Maguire \& Phillips, 2008), and political (Hambrick \& Cannella, 1993) factors-is an inherent part of postmerger dynamics that should be taken seriously to better understand the unfolding of postmerger organizational change.

This analysis helps explain some of the problems and disappointments often experienced in M\&As. An initial focus on sociopolitical concerns and equality helps to "sell" a merger to 
stakeholders and facilitate early integration efforts, yet it may eventually undermine the ability to reap full synergy potential. However, when pressure to create value mounts, management needs to shift the focus to equity. If done too early, too late, or too abruptly, such a shift may lead to problems, because employees' expectations are violated. Our analysis thus adds an explicit processual explanation to the study of success and failure in M\&As (Larsson \& Finkelstein, 1999; Stahl \& Voigt, 2008).

The analysis of dialogical sensegiving and sensemaking processes advances research on intergroup dynamics in postmerger integration more generally. Studies of cultural dynamics (Vaara \& Tienari, 2011) and identity formation (Clark et al., 2010; Maguire \& Phillips, 2008) have highlighted the mutual dependence of managerial actions and organizational responses in postmerger organizations. Our analysis complements these studies by elucidating how the very rules of the game are negotiated and how these negotiations lead or do not lead to alignment-with important implications for the course of postmerger integration. Thus, our study highlights a crucial but poorly understood aspect of the co-constructed nature of postmerger reality.

Our study also adds to the previous studies on communication, which have rarely elaborated on how organizational interaction unfolds over time in M\&As (Schweiger \& DeNisi, 1991). The SouthcoNorthco case demonstrates how managers can steer the course of integration by management of meaning (Graebner, 2004; Vaara \& Tienari, 2011) and how this involves not only conventional sensegiving but a variety of modes such as sensebreaking, sense specification, and sensehiding. Furthermore, our analysis sheds new light on the crucial role of organizational reactions, underscoring the polyphony and ambivalence (Piderit, 2000; Sonenshein, 2010) characterizing these communicative processes. Importantly, although previous studies have focused on communication as a means to reduce ambiguity (Risberg, 2001; Vaara, 2003), our case clearly illustrates that at times ambiguity is needed to deal with the pressures of postmerger integration.

The central role of discourse in all this sensegiving and sensemaking cannot be overstated. Our case adds to previous studies on management of meaning in the M\&A context (Vaara \& Monin, 2010) by demonstrating that mobilizing existing discourses, inventing new ones, and silencing alternative ones is the essence of sensegiving. It also provides ample evidence of the evocative power of catch phrases, metaphors, and other creative labels, such as "don't go east" or "majority rule," that are coined by top managers but in many cases also by employees. Furthermore, by focusing on the continuous dialogue, our case helps to explain why and how some of these discourses take while others do not.

Postmerger integration involves power and politicization (Graebner, 2004; Hambrick \& Cannella, 1993; Vaara, 2003). The Southco-Northco case demonstrates how the social construction of power relations and norms of justice go hand in hand and often reinforce each other. In particular, symbiotic mergers often bring with them accentuated expectations of equality and attention to distributive bargaining (Hambrick \& Cannella, 1993; Walton \& McKersie, 1965). Our case illustrates how difficult it is to maintain a balance of power and what it implies to shift from equality to equity. By offering this case, we complement previous research focusing on the specific political challenges of mergers and mergers of equals (Hambrick \& Cannella, 1993; Vaara, 2003).

Although we have focused on the M\&A context, our analysis also contributes more generally to research on organizational justice. Existing research has shown that perceptions of justice impact employees' attitudes toward cooperation and behaviors at work (Colquitt \& Rodell, 2011; Greenberg \& Cropanzano, 2001). However, much less is known about the social construction of norms of justice as part of organizational change (Fortin \& Fellenz, 2008; Watson, 2003). We have highlighted how norms of justice are socially constructed in organizational change processes. Specifically, we have shed more light on one of the most central questions in contemporary research on justice: how exactly norms of equality and equity complement each other and change over time (Deutsch, 1985; Kabanoff, 1991). Extant justice research has focused on reactive aspects of justice. In contrast, the proactive creation of norms of justice is poorly understood, even though anecdotal evidence suggests that executives at the apex of radical organizational change such as an M\&A purposefully choose and promote specific norms of justice (Vlasic \& Stertz, 2000). By explaining how managers give sense to justice, our analysis sheds more light on the political power that rests with them as potential norm setters (Fortin \& Fellenz, 2008). Finally, by focusing attention on the dialogical processes of sensegiving and sensemaking, our analysis highlights the complexities, ambiguities, and contradictions around norms of justice that conventional approaches often fail to recognize.

Our analysis reveals aspects of sensegiving and sensemaking that may be helpful in advancing a more nuanced understanding of the politics of sen- 
semaking, as has been called for in research on sensemaking (Maitlis \& Sonenshein, 2010). In particular, by distinguishing how sensebreaking, sense specification, and sensehiding affect the dynamics of organizational sensemaking in specific ways, our analysis adds to research on sensegiving. In our analysis, sensebreaking had a crucial role in steering sensemaking toward new understandings. Thus, in the manner of Pratt (2000) and Mantere et al. (2012), our analysis underscores the fundamental role that breaking previous understandings plays in major organizational change such as M\&A. It was also shown that various forms of sense specification are needed to specify meanings. Furthermore, our analysis elucidates how deliberate sensehiding was an essential part of sensegiving-an aspect that has received little attention in previous research (see also Vaara \& Monin, 2010). In addition, by elaborating a range of organizational reactions from acceptance to resistance to distancing, we show that the effects of any sensegiving will depend on sensemaking by organization members. Thus, this analysis elucidates both the power and powerlessness of managers and, more generally, illuminates the role of political agency in sensemaking.

Finally, all this also has implications for the process studies approach. Our analysis shows how the dialectics of value creation and sociopolitical concerns impact the course of postmerger integration and how these contradictory pressures are given sense to and made sense of in ongoing dialogical processes. Conceptually, both dialectics (Van de Ven \& Poole, 1995) and dialogicality (Boje, 2008) capture important aspects of the dynamic nature of organizational change processes. However, an indepth understanding of the process dynamics of organizational change requires that attention focus on both the contradictory pressures (dialectics) and the way in which organizational actors give sense to and make sense of these pressures (dialogicality). Our model is certainly not the only way to link these dynamics together, yet it does provide a potentially useful framework for analyzing process dynamics in other contexts.

Our findings are most relevant for symbiotic cases (Haspeslagh \& Jemison, 1991), especially for so-called mergers of equals (Meyer, 2001; Zaheer et al., 2003). Nevertheless, other types of M\&A may well involve difficult issues related to justice and dynamics that deserve special attention. For example, more straightforward takeovers and controloriented integration approaches-"absorption" (Haspeslagh \& Jemison, 1991), "redesign" (Napier, 1989), and "control" (Larsson, 1990)—would likely focus more on value creation from the start, at the risk of neglecting sociopolitical issues. How these dynamics play out in different types of M\&A is an important challenge for future research. Moreover, given the revelatory nature of our case, the role of justice may have been accentuated more than in other circumstances. Thus, our findings need to be compared with other cases.

Although distributive justice is arguably the central tenet of justice in symbiotic M\&As, other aspects, such as procedural justice, informational justice, and interpersonal justice (Colquitt et al., 2001), deserve attention in future research. Furthermore, there is a need to extend the analysis of the intergroup dynamics uncovered in this study. In particular, studies could elaborate on the crucial role of middle managers as boundary spanners (Balogun \& Johnson, 2004; Rouleau, 2005). It would also be interesting to examine in more detail the discursive dynamics identified in our analysis. Finally, as this analysis has shown, dialogical analysis has the potential to uncover important process dynamics in organizational change, and we hope that this study will be followed by new ones, both in M\&As and in other contexts.

\section{REFERENCES}

Adams, J. S. 1965. Inequity in social exchange. In L. Berkowitz (Ed.), Advances in experimental social psychology, vol. 2: 267-299. New York: Academic Press.

Ambrose, M. L., \& Cropanzano, R. 2003. A longitudinal analysis of organizational fairness: An examination of reactions to tenure and promotion decisions. Journal of Applied Psychology, 88: 266-275.

Ariño, A., \& Smith Ring, P. 2010. The role of fairness in alliance formation. Strategic Management Journal, 31: 1054-1087.

Badrtalei, J., \& Bates, L. D. 2007. Effect of organizational cultures on mergers and acquisitions: The case of DaimlerChrysler. International Journal of Management, 24: 303-317.

Balogun, J., \& Johnson, G. 2004. Organizational restructuring and middle manager sensemaking. Academy of Management Journal, 47: 523-549.

Bartunek, J. M., Rousseau, D. M., Rudolph, J. W., \& DePalma, J. A. 2006. On the receiving end: Sensemaking, emotion and assessments of an organizational change initiated by others. Journal of Applied Behavioral Science, 42: 182-206.

Birkinshaw, J., Bresman, H., \& Håkanson, L. 2000. Managing the post-acquisition integration process: How the human integration and task integration processes interact to foster value creation. Journal of Management Studies, 37: 395-425. 
Boje, D. M. 2008. Storytelling in organizations. Thousand Oaks, CA: Sage.

Buono, A. F., \& Bowditch, J. L. 1989. The human side of mergers and acquisitions: Managing collisions between people, cultures, and organizations. San Francisco: Jossey-Bass.

Citera, M., \& Rentsch, J. R. 1993. Is there justice in organizational acquisitions? The role of procedural and distributive fairness in corporate acquisitions. In R. Cropanzano (Ed.), Justice in the workplace: Approaching fairness in human resource management: 211-230. Hillsdale, NJ: Erlbaum.

Clark, S. M., Gioia, D. A., Ketchen, D. J., \& Thomas, J. B. 2010. Transitional identity as a facilitator of organizational identity change during a merger. Administrative Science Quarterly, 55: 397-438.

Colquitt, J. A., Conlon, D. E., Wesson, M. J., Porter, C. O. L. H., \& Ng, K. Y. 2001. Justice at the millennium: A meta-analytic review of 25 years of organizational justice research. Journal of Applied Psychology, 86: 425-445.

Colquitt, J. A., \& Rodell, J. B. 2011. Justice, trust, and trustworthiness: A longitudinal analysis integrating three theoretical perspectives. Academy of Management Journal, 54: 1183-1206.

Cording, M., Christmann, P., \& King, D. R. 2008. Reducing causal ambiguity in acquisition integration: Intermediate goals as mediators of integration decisions and acquisition performance. Academy of Management Journal, 51: 744-767.

Czarniawska, B. 2004. Narratives in social science research. London: Sage.

Denis, J.-L., Dompierre, G., Langley, A., \& Rouleau, L. 2011. Escalating indecision: Between reification and strategic ambiguity. Organization Science, 22: 225244.

Deutsch, M. 1985. Distributive justice: A social-psychological perspective. New Haven: Yale University Press.

Dutton, J. E., \& Ashford, S. J. 1993. Selling issues to top management. Academy of Management Review, 18: $397-428$

Dutton, J. E., \& Dukerich, J. M. 1991. Keeping an eye on the mirror-Image and identity in organizational adaption. Academy of Management Journal, 34: 517-554.

Ellis, K. M., Reus, T. H., \& Lamont, B. T. 2009. The effects of procedural and interactional justice in the integration of related acquisitions. Strategic Management Journal, 30: 137-161.

Fortin, M., \& Fellenz, M. R. 2008. Hypocrisies of fairness: Towards a more reflexive ethical base in organizational justice and practice. Journal of Business Ethics, 78: 415-433.
Giessner, S. R., Viki, G. T., Otten, S., Terry, D. J., \& Täuber, S. 2006. The challenge of merging: Merger patterns, premerger status, and merger support. Personality and Social Psychology Bulletin, 32: 339352.

Graebner, M. E. 2004. Momentum and serendipity: How acquired leaders create value in the integration of technology firms. Strategic Management Journal, 25: 751-777.

Greenberg, J., \& Cropanzano, R. 2001. Advances in organizational justice. Stanford, CA: Stanford University Press.

Hambrick, D. C., \& Cannella, A. A. 1993. Relative standing: A framework for understanding departures of acquired executives. Academy of Management Journal, 36: 733-762.

Haspeslagh, P. C., \& Jemison, D. B. 1991. Managing acquisitions: Creating value through corporate renewal. New York: Free Press.

Hernes, T., \& Maitlis, S. 2010. Process, sensemaking and organizing. Oxford, U.K.: Oxford University Press.

Jemison, D. B., \& Sitkin, S. B. 1986. Corporate acquisitions-A process perspective. Academy of Management Review, 11: 145-163.

Kabanoff, B. 1991. Equity, equality, power, and conflict. Academy of Management Review, 16: 416-441.

Klendauer, R., \& Deller, J. 2009. Organizational justice and managerial commitment in corporate mergers. Journal of Managerial Psychology, 24: 29-45.

Langley, A. 1999. Strategies for theorizing from process data. Academy of Management Review, 24: 691710 .

Langley, A., \& Tsoukas, H. 2010. Introducing perspectives on process organization studies. In T. Hernes \& S. Maitlis (Eds.), Process, sensemaking, and organizing: 1-26. Oxford, U.K.: Oxford University Press.

Larsson, R. 1990. Coordination of action in mergers and acquisitions: Interpretive and systems approaches towards synergy. Lund, Sweden: Lund University Press.

Larsson, R., \& Finkelstein, S. 1999. Integrating strategic, organizational, and human resource perspectives on mergers and acquisitions: A case survey of synergy realization. Organization Science, 10: 1-27.

Leventhal, G. S. 1976. Fairness in social relationships. In J. W. Thibaut, J. T. Spence, \& R. C. Carson (Eds.), Contemporary topics in social psychology: 211239. Morristown, NJ: General Learning Press.

Lipponen, J., Olkkonen, M.-E., \& Moilanen, M. 2004. Perceived procedural justice and employee responses to an organizational merger. European Journal of Work and Organizational Psychology, 13: $391-413$ 
Luo, Y. D. 2007. Are joint venture partners more opportunistic in a more volatile environment? Strategic Management Journal, 28: 39-60.

Maguire, S., \& Phillips, N. 2008. "Citibankers" at Citigroup: A study of the loss of institutional trust after a merger. Journal of Management Studies, 45: $372-401$.

Maitlis, S. 2005. The social processes of organizational sensemaking. Academy of Management Journal, 48: 21-49.

Maitlis, S., \& Lawrence, T. B. 2007. Triggers and enablers of sensegiving in organizations. Academy of Management Journal, 50: 57-84.

Maitlis, S., \& Sonenshein, S. 2010. Sensemaking in crisis and change: Inspiration and insights from Weick (1988). Journal of Management Studies, 47: 551580.

Mantere, S., Schildt, H., \& Sillince, J. A. A. 2012. Reversal of strategic change. Academy of Management Journal, 55: 172-196.

Marmenout, K. 2010. Employee sensemaking in mergers: How deal characteristics shape employee attitudes. Journal of Applied Behavioral Science, 46: 329359.

McFarlin, D. B., \& Sweeney, P. D. 1992. Distributive and procedural justice as predictors of satisfaction with personal and organizational outcomes. Academy of Management Journal, 35: 626-637.

Meyer, C. B. 2001. Allocation processes in mergers and acquisitions: An organizational justice perspective. British Journal of Management, 12: 47-66.

Meyer, C. B., \& Altenborg, E. 2007. The disintegrating effects of equality: A study of a failed international merger. British Journal of Management, 18: 257271.

Napier, N. K. 1989. Mergers and acquisitions, human resource issues and outcomes: A review and suggested typology. Journal of Management Studies, 26: 271-289.

Piderit, S. K. 2000. Rethinking resistance and recognizing ambivalent attitudes toward organizational change: A multidimensional view. Academy of Management Review, 25: 783-794.

Pratt, M. G. 2000. The good, the bad, and the ambivalent: Managing identification among Amway distributors. Administrative Science Quarterly, 45: 456-493.

Rawls, J. 1971. A theory of justice. Cambridge,U.K.: Harvard University Press.

Ring, P. S., \& Van de Ven, A. H. 1994. Developmental processes of cooperative inter-organizational relationships. Academy of Management Review, 19: 90-118.
Risberg, A. 2001. Employee experiences of acquisition processes. Journal of World Business, 36: 58-84.

Rouleau, L. 2005. Micro-practices of strategic sensemaking and sensegiving: How middle managers interpret and sell change every day. Journal of Management Studies, 42: 1413-1441.

Rubinstein, D. 1988. The concept of justice in sociology. Theory and Society, 17: 527-550.

Schweiger, D. M., \& DeNisi, A. S. 1991. Communication with employees following a merger-A longitudinalfield experiment. Academy of Management Journal, 34: 110-135.

Schweizer, L. 2005. Organizational integration of acquired biotechnology companies into pharmaceutical companies: The need for a hybrid approach. Academy of Management Journal, 48: 1051-1074.

Sonenshein, S. 2010. We're changing or are we? Untangling the role of progressive, regressive and stability narratives during strategic change implementation. Academy of Management Journal, 53: 477-512.

Stahl, G. K., \& Voigt, A. 2008. Do cultural differences matter in mergers and acquisitions? A tentative model and examination. Organization Science, 19: 160-176.

Stensaker, I., \& Falkenberg, J. 2007. Making sense of different responses to corporate change. Human Relations, 60: 137-177.

Tsoukas, H. 2009. A dialogical approach to the creation of new knowledge in organizations. Organization Science, 20: 941-957.

Vaara, E. 2003. Post-acquisition integration as sensemaking: Glimpses of ambiguity, confusion, hypocrisy, and politicization. Journal of Management Studies, 40: 859-894.

Vaara, E., \& Monin, P. 2010. A recursive perspective on discursive legitimation and organizational action in mergers and acquisitions. Organization Science, 21: 3-22.

Vaara, E., \& Tienari, J. 2011. On the narrative construction of MNCs: An antenarrative analysis of legitimation and resistance in a cross-border merger. Organization Science, 22: 370-390.

Van de Ven, A. H., \& Poole, M. S. 1995. Explaining development and change in organizations. Academy of Management Review, 20: 510-540.

Very, P., Lubatkin, M., Calori, R., \& Veiga, J. 1997. Relative standing and the performance of recently acquired European firms. Strategic Management Journal, 18: 593-614.

Vlasic, B., \& Stertz, B. A. 2000. Taken for a ride: How Daimler-Benz drove off with Chrysler. New York: HarperBusiness. 
Walter, G. A. 1985. Culture collisions in mergers and acquisitions. In P. J. Frost, L. F. Moore, M. R. Louis, C. C. Lundberg, \& J. Martin, (Eds.), Organizational culture: 301-314. Beverly Hills, CA: Sage.

Walton, R. E., \& McKersie, R. B. 1965. A behavioral theory of labor negotiations: An analysis of a social interaction system. New York: McGraw-Hill.

Watson, G. W. 2003. Ideology and the symbolic construction of fairness in organizational change. Journal of Organizational Change Management, 16: 154168.

Weick, K. E. 1995. Sensemaking in organizations. Thousand Oaks, CA: Sage.

Zaheer, S., Schomaker, M., \& Genc, M. 2003. Identity versus culture in mergers of equals. European Management Journal, 21: 185-191.

\section{$M$}

Philippe Monin (monin@em-lyon.com) is the TOUPARGEL Chair Professor of Strategic Management and vice president of research at EMLYON Business School. He received his Ph.D. at Université Jean Moulin Lyon III. His eclectic research interests focus on postintegration processes in mergers and acquisitions, market building in BoP markets, institutions and social movements, and markets for critical opinion.
Niels Noorderhaven (n.g.noorderhaven@tilburguniversity. edu) is a professor of international management and the director of the Center for Innovation Research at Tilburg University. He received his Ph.D. from University of Groningen. His research focuses on (international) cooperation in business, with a special interest in human factors and learning. His current research focuses on justice and identity in interorganizational collaboration and in mergers and acquisitions, and on the social construction of perceptions of interests.

Eero Vaara (eero.vaara@hanken.fi) is a professor of management and organization and the dean of research at Hanken School of Economics in Helsinki and permanent visiting professor at EMLYON Business School. He received his Ph.D. at Helsinki School of Economics. His research interests focus on strategy and strategizing, organizational change, multinational corporations and globalization, management education, and methodological issues in management research. He has worked especially on discursive and narrative perspectives.

David Kroon (d.p.kroon@vu.nl) is an assistant professor of strategic management at the Faculty of Economics and Business Administration of VU University Amsterdam. He received his Ph.D. from Tilburg University. His current research focuses on interorganizational collaboration, organizational change, and postmerger integration, with a particular emphasis on identity/identification, justice, culture, communication, and trust. 
Copyright of Academy of Management Journal is the property of Academy of Management and its content may not be copied or emailed to multiple sites or posted to a listserv without the copyright holder's express written permission. However, users may print, download, or email articles for individual use. 